\title{
TANDEMOVÉ KOJENÍ JAKO SPECIFICKÝ PROSTŘEDEK KONTAKTNÍHO RODIČOVSTVÍ - ZKUŠENOSTI MATEK
}

\author{
Veronika Hanáčková, Zuzana Masopustová
}

\begin{abstract}
Abstrakt
Fenomén tandemového kojení nebyl $\mathrm{v}$ psychologickém výzkumu zatím př́liš zachycen. Tandemové kojení bývá praktikováno některými matkami, které následují trend tzv. kontaktního rodičovství. Při tandemovém kojení matka kojí mladší i starší dítě zároveň. Se čtyřmi ženami, které se hlásí ke kontaktnímu rodičovství a tandemově kojí dítě v batolecím věku spolu $\mathrm{s}$ jeho starším sourozencem $\mathrm{v}$ předškolním věku, byly provedeny hloubkové rozhovory. Pro analýzu dat byla použita interpretativní fenomenologická analýza (IPA), s jejíž pomocí byla identifikována čtyři hlavní témata: 1) Snaha udržet kojení za každou cenu - od útlumu kojení v těhotenství, po prudký nárůst po porodu až k ideálu samoodstavu; 2) Matka uprostřed - „Připadám si, že jsem pořád ... pořád mezi dětma...fyzicky a psychicky... uprostřed“; 3) Tandemové kojení jako jistota pro starší dítě v novém uspořádání rodiny a snaha matky o podporu sourozeneckých vztahů; 4) Podpora i kritika tandemového kojení vedoucí k upevnění přesvědčení.
\end{abstract}

Klíčová slova: tandemové kojení, kojení, kontaktní rodičovství, interpretativní fenomenologická analýza

\section{TANDEM NURSING AS SPECIFIC MEANS OF ATTACHMENT PARENTING - MOTHERS' EXPERIENCES}

\begin{abstract}
The phenomenon of tandem nursing has not been much captured by psychological research. Tandem nursing is practiced by some mothers who follow the trend of attachment parenting. In tandem nursing, the mother breastfeeds both the younger and the older child at the same time. In-depth interviews were conducted with four women who claimed to practice attachment parenting and breastfed their toddler child together with their older sibling at preschool age. Interpretative phenomenological analysis (IPA) was used to analyze the data, and four main themes were identified: 1) Efforts to maintain breastfeeding at all costs - from the decline of breastfeeding in pregnancy to the sharp increase after childbirth to the ideal of selfreinstatement; 2) Mother in the middle - "I feel like I'm still...always in the middle...physically and mentally...between the children"; 3) Tandem nursing as a safeguard for the older child in the new family structure and the mother's efforts to support sibling relationships; 4) Support and criticism of tandem nursing leading to reinforcement of beliefs.
\end{abstract}

Keywords: tandem nursing, breastfeeding, attachment parenting, interpretative phenomenological analysis

Došlo do redakce: 21.4 .2021

Schváleno k publikaci: 10. 12. 2021 


\section{ÚVOD}

\section{Kojení jako klíčové téma posledních let}

Krmení dítěte je téma, se kterým se matky ve vyspělých zemích většinou setkávají již před samotným porodem, minimálně $\mathrm{v}$ rámci předporodních kurzů péče o dítě (Newman \& Williamson, 2018). Na tuto oblast je zejména v poslední době zaměřená velká pozornost (Wolf, 2013). Na rozdíl od výrazné části minulého století vyznačující se velkým boomem v prosazování umělé výživy a akcentace výhod tohoto způsobu krmení dítěte, se v současné době klade důraz na propagaci kojení a z toho plynoucí benefity (Rollins et al., 2016). Kojení je tedy nyní považováno za výživu prospěšnou jak pro zdraví matky, tak pro zdraví a vývoj dítěte (Slusser, 2007).

Velká většina evropských vlád podporuje závěry WHO doporučující výhradní kojení dětí do šesti měsíců věku života a poté společně s běžným jídlem do dvou let a dále podle potřeb dítěte (Dowling \& Brown, 2013). Trend propagace kojení se odráží v rostoucím poměru kojících žen v Evropě (Rollins et al., 2016). Theurich a kolektiv (2019) provedli průzkum kojení v jedenácti evropských zemích a zjistili, že se procento výhradně kojených dětí v šesti měsících věku dítěte mezi jednotlivými zeměmi poměrně liší. Např́iklad se zjistilo, že v šesti měsících věku dítěte je nejnižší procento kojených dětí v Itálii (38 \%) a nejvyšší v Norsku (71\%) (Theurich et al., 2019). Že je situace v kojení různá napříč Evropou, dokazují i jednotlivé studie zaměřuící se na výzkum kojení. Dowlingová a Pontin (2015) uvádějí, že i přes propagaci kojení je v Anglii v šesti měsících věku výhradně kojeno pouze $1 \%$ dětí a v nějaké formě (společně s příkrmy) je kojeno $34 \%$ dětí, zatímco například na Islandu je v šesti měsících věku dítěte kojeno 74 \% dětí (Símonardóttir, 2016). Island patří k zemím, ve kterých je dlouhodobě procento kojících žen nejvyšší na světě (Símonardóttir \& Gíslason, 2018).

V České republice chybí ucelený přehled poměru kojících žen, proto není možné tyto údaje porovnávat přesně, nicméně $\mathrm{v}$ rámci studie zaměřující se na mateřství v České republice bylo zjištěno, že ze 729 žen zapojených do výzkumu (specifika výzkumného souboru viz Masopustová a kol., 2018) výhradně kojilo ve třech měsících věku dítěte $72 \%$ žen a dalších cca $12 \%$ žen sice nekojilo výhradně, ale nějaká forma kojení byla stále přítomná (většinou s podáváním příkrmů umělým mlékem).Dá se tedy říct, že velká většina dětí (cca $85 \%$ ) byla ve třech měsících ještě kojená. Dále bylo od respondentek retrospektivně ve třech letech věku dítěte zjištěno, že cca $76 \%$ žen stále kojilo ve věku šesti až dvanácti měsíců věku dítěte (Masopustová et al., 2018), nicméně ve věku tř́ let bylo do výzkumu zapojeno pouze 146 žen. I tak tato data ale naznačují, že je poměr kojících žen v České republice v rámci Evropy vyšší a podobný spíše situaci na Islandu než např́klad v Anglii, kde velká většina žen mezi šestým a dvanáctým měsícem života dítěte již nekojí (Dowling \& Brown, 2013).

\section{Kojení jako praktika "dobrého rodičovství"}

Zatímco dříve bylo kojení vnímáno a akcentováno zejména pro své zdravotní benefity, které jsou potvrzeny i řadou výzkumů (např. Duncan, 1993; Kull et al., 2002; Oddy et al., 2007), v současnosti bývá poukazováno na přesah kojení až do oblasti rodičovství a výchovy celkově (Dykes \& Flacking, 2010). Téma kojení přestalo být pouze způsobem krmení dítěte, ale stalo se z něj částečně i vyjádření určitého postoje k mateřství a rodičovství (Símonardóttir, 2016) a v poslední době na něj bývá nahlíženo jako na něco, co představuje tzv. "dobré rodičovství" 
(Dykes \& Flacking, 2010). Kojení je v západních zemích právem pro své nezanedbatelné benefity sahající nejen do zdravotní oblasti prezentováno jako jakýsi “ideál” a optimální způsob výživy dítěte a stává se normou, o kterou by se podle společenských očekávání měly matky snažit (Watkinson, Murray \& Simpson, 2016). S velkým důrazem na kojení se setkávají ženy již v rámci předporodních kurzů, na kterých se učí, jak správně své dítě kojit a kde je kojení často podáváno jako ten nejlepší způsob krmení dítěte (Símonardóttir \& Gíslason, 2018). Důraz na kojení, minimálně v kontextu většiny evropských zemí, poté pokračuje i v porodnicích, ve kterých jsou matky primárně vedeny ke kojení (Dowling \& Brown, 2013).

Společně se snahou o zvýšení poměru kojících žen v Evropě a ve vyspělých západních zemích se tedy objevuje i větší tlak na ženy, aby kojily (Newman \& Williamson, 2018). Tím, že se z kojení stává norma a ideál, který by se měl následovat (Watkinson, Murray \& Simpson, 2016), se u nekojících žen mohou objevovat pocity selhání a viny z toho, že "porušují pravidla" (Lee \& Bristow, 2009) a nejednají v souladu s tím, co je "nejlepší pro jejich dítě" (Murphy, 1999). Výzkumy naznačují, že snaha uspět v kojení a očekávání od rodičovství jsou úzce spojeny (Hauck \& Irurita, 2003; Marshall, 2011) a pokud dojde k selhání u kojení, může to mít dopad i na vnímání sebe sama jako dobré matky (Larsen \& Kronborg, 2012). Thompsonová a kol. (2015) zdůrazňují, že právě krmení dětí je něco, co bývá často okolím hodnoceno a vnímáno jako synonymum mateřských schopností, což může mít výrazně negativní vliv na sebevědomí matek, a to u nekojících, ale i kojících žen.

Kojení je podáváno spíše jako přirozená dovednost, kterou mají matky od př́rody než jako kompetence, kterou si matky mohou osvojit nebo se naučit. Právě tato perspektiva často opomíjí problémy, které se s kojením mohou pojit, a to zejména v počátcích kojení (Watkinson, Murray \& Simpson, 2016). Yate (2017) navíc uvádí, že jsou při kojení zobrazovány zejména usmívající se a št'astné matky, které nemají s kojením žádné problémy, což může vést k nerealistickým očekáváním od kojení u žen. Kojení a s tím související realizace v mateřství a rodičovství je podáváno a prezentováno jako činnost, ve které by měly být matky emočně zaangažovány a která by je měla po všech stránkách naplňovat (Lee \& Bristow, 2009). Ve skutečnosti má ale poměrně dost žen problémy s kojením jako takovým (Símonardóttir \& Gíslason, 2018) nebo zažívá u kojení negativní emoce (Heise \& Wiessinger, 2011), což opět může přispívat k tomu, že pocity viny a selhávání zažívají i matky, které kojí (Yate, 2017).

Watkinson, Murray a Simpson (2016) provedli rozhovory s jedenácti matkami, které zažily v posledních pěti letech negativní emoce spojené s kojením. Jednalo se o matky, které měly velmi silně vyhraněné racionální přesvědčení o prospěšnosti kojení a které si velmi přály své dítě kojit. Uváděly, že kojení považují za výraznou součást své "mateřské identity" a "to nejlepší, co mohou pro své dítě udělat". Ve svém prožívání se poté dostávaly do konfliktu, protože během kojení zažívaly pocity vzteku, frustrace a další negativní emoce, o kterých vypovídaly, že je "zažívat nechtěly". Vzhledem k tomu, že o kojení mluvily tyto respondentky jako o základní a důležité složce svého mateřství, zažívaly výrazné pocity selhání, když se při kojení cítily jinak, než by si přály. Do tohoto výzkumu byly zahrnuty i ty ženy, které v době výzkumu již nekojily (pouze měly v předešlých letech zkušenost s negativními emocemi u kojení). Rozpětí „délky kojení“ u žen bylo velmi široké - od pěti měsíců věku dítěte do více než 48 měsíců. Některé z žen kvůli svým pocitům kojit přestaly. Autoři (Watkinson, Murray, \& Simpson, 2016) upozorňují, že se tedy jedná o velmi rozmanitou skupinu respondentek a 
další výzkumy by se mohly zaměřit na ženy kojící skutečně dlouhodobě a ty, které setrvávají u kojení i přes negativní pocity, které prožívají.

Yate (2017) se ve svém výzkumu zaměřil na prožívání averze vůči dítěti během kojení. Do výzkumu bylo zapojeno 694 matek, které vyplňovaly dotazníky ohledně kojení. Yate (2017) zjistil, že se averze vůči dítěti objevuje často u kojení během těhotenství s dalším dítětem a během tzv. tandemového kojení (tedy kojení dvou dětí zároveň). Je zajímavé, že i přes tyto negativní pocity a zážitky kojily matky své dítě často déle než do kojeneckého věku a často se u nich objevovalo kojení tzv. "na přání dítěte" (tedy že dítě určuje frekvenci a trvání kojení). Opět, jako ve výzkumu Watkinsona, Murraye a Simpsona (2016), zde ženy často popisovaly touhu v kojení pokračovat, protože kojení považovaly za něco, co "dělají v prvé řadě pro dítě" a co přispívá k vazbě mezi matkou a dítětem. Yates (2017) polemizuje, zda v př́ípadě, když matka zažívá dlouhodobě pocity averze a vzteku na dítě, které se chce stále kojit, kojení opravdu přispívá $\mathrm{k}$ dobrému vztahu mezi matkou a dítětem. Nicméně, vzhledem ke kvantitativní povaze výzkumu mají jeho závěry povahu pouze předběžných zjištění, a proto autor doporučuje, aby se budoucí výzkumné směřování zaměřilo více a podrobněji na specifické skupiny žen, kterých se pocity averze u kojení mohou týkat, např. ženy kojící během těhotenství, v tandemu nebo ženy kojící starší děti (Yates, 2017).

Morns a kolektiv (2019) provedli review pěti kvalitativních výzkumů z let 2010-2019 zaměřujících se na problematiku prožívání averze vůči dítěti během kojení. Závěry všech výzkumů analyzovali a došli k závěru, že se jedná o velmi silné pocity, které žena sice chce ovlivnit, ale má pocit, že nemůže, a že mnoho žen v kojení pokračuje, přestože jim nevyhovuje. Matky si to zdůvodňují tak, že „dělají to nejlepší pro své dítě“, a proto ho kojí mnohdy delší dobu, než do ukončeného kojeneckého věku (Morns et al., 2019). Zároveň bylo zjištěno, že by tyto pocity mohly souviset s hormonální hladinou ženy, jelikož se objevovaly více u žen těhotných s dalším dítětem a žen kojících tandemově, proto autoři doporučují další výzkumy zaměřit právě na tyto skupiny žen a jejich prožívání během kojení (Morns et al., 2019). Problémem analyzovaných výzkumů je opět heterogenní vzorek, což může být v kvalitativním výzkumu problematické - do zkoumání byly zahrnuty různé skupiny žen kojících různě dlouhou dobu, a navíc pocházející z mnohdy rozmanitých kulturních prostředí. Kromě toho autoři (Morns et al., 2019) upozorňují na skutečnost, že se často jednalo o ženy tzv. „dlouhodobě“ kojící v zemích, kde obecně kojí poměrně nízké procento žen (například Velká Británie), a proto jsou za dlouhodobě kojící považovány i ty ženy, které kojí dítě starší šesti měsíců, což je v jiných zemích, např. na Islandu, považováno za běžnou délku kojení (Símonardóttir, 2016) a je tedy otázkou, zda se negativní pocity žen nemohou vázat např́íklad na vybočení z nějakých společenských očekávání.

Závěry prezentovaných výzkumů (Watkinson, Murray, \& Simpson, 2016; Yate, 2017; Morns et al., 2019) poukazují to, že negativní pocity a pocity averze vůči dítěti zažívá poměrně velké množství žen, a to zejména u dlouhodobého kojení, tj. kojení dětí starších než půl roku, př́ípadně rok. Tyto ženy se ale snaží i přes negativní pocity v kojení pokračovat (Yate, 2017), protože kojení považují za důležité téma a součást svého rodičovství (Watkinson, Murray, \& Simpson, 2016; Morns et al., 2019). Podle zjištění Mornse a kol. (2019) se negativní pocity a pocity averze objevují např́klad během tandemového kojení, což je téma, které obecně zatím není př́liš prozkoumané ( $\mathrm{O}^{\prime}$ Rourke, 2018), a proto by mohlo být zajímavé výzkumně zaměřit právě na prožívání kojení u žen kojících tandemově. Vzhledem k nejasnostem ohledně 
operacionalizace pojmu „dlouhodobé kojení“ by bylo vhodné do výzkumu zařadit ženy, které kojí děti i v průběhu a po batolecím období (Morns et al., 2019) a to i v zemích, kde je kojení během prvního roku života dítěte běžnější než ve zmiňovaných studiích.

\section{Kontaktní rodičovství a dlouhodobé kojení}

Velká důležitost a význam kojení jsou reflektovány také v poslední době populárních rodičovských trendech charakterizovaných zaměřením na dítě a stavějících matku do nenahraditelné a nezastupitelné pozice osoby, která je pro dítě neustále dostupná (Maher \& Saugeres, 2007). Tyto trendy jsou na vzestupu zejména ve vyspělých západních zemích (Crossey, 2009) a jdou ruku v ruce s důrazem na kojení a jeho propagaci (Símonardóttir, 2016). Mezi typické představitele takového trendu patří kontaktní rodičovství (Faircloth, 2009). Kontaktní rodičovství je př́stup k dítěti charakterizovaný důrazným akcentem na uspokojování potřeb dítěte, mezi jehož prostředky patří společné spaní s dítětem, nošení dítěte $\mathrm{v}$ šátku nebo nosítku a zejména dlouhodobé kojení dítěte (často až do samoostavu) (Símonardóttir, 2016). Řada výzkumů zaměřujících se na ženy kojící dlouhodobě zjišt’uje, že se právě tyto ženy často s principy kontaktního rodičovství ztotožňují (napřs. Faircloth, 2010; Símonardóttir, 2016; Thompson, Topping \& Jones, 2020).

Výzkum mateřství na Islandu (Símonardóttir, 2016) uvádí, že Island je jednou ze zemí, ve kterých je popularita kontaktního rodičovství velmi patrná. Jak již bylo výše zmíněno, právě na Islandu se vyskytuje jeden z nejvyšších poměrů kojících žen na světě (Símonardóttir \& Gíslason, 2018). Podobně jako na Islandu, i v České republice je kojení během prvního roku života dítěte hojně zastoupeno (Masopustová a kol., 2018). Ve výzkumu mateřství, jehož se účastnilo 439 žen, uvedlo $23 \%$ žen jako trend, který následují, kontaktní rodičovství (Masopustová a kol., 2018). Výzkumný soubor však byl nabrán formou samovýběru. Nelze tedy extrapolovat na celou populaci matek v ČR. Lze se ale domnívat, že kontaktní rodičovství není v ČR neznámým či okrajovým trendem a spíše se bude řadit mezi populární trendy.

Jak již bylo výše uvedeno, významnou součástí kontaktního rodičovství je důraz na kojení, zejména na tzv. dlouhodobé kojení (Faircloth, 2010). Dlouhodobé kojení (extended breastfeeding) je termín široce používaný v zahraničí v souvislosti s kontaktním rodičovstvím a je charakterizován kojením dítěte dlouhou dobu, často až do samoodstavu (Stearns, 2011). V rámci výzkumů je za dlouhodobé kojení považováno kojení nad šest měsíců věku dítěte (např. Newman \& Williamson, 2018) nebo př́ípadně nad jeden rok (např. Säilävaara, 2019). Jak ale upozorňují mnozí autoři zaměřující se na výzkum dlouhodobého kojení (např. Morns a kol., 2019; Faircloth, 2010b), v navazujících výzkumech by bylo potřeba tento termín lépe operacionalizovat a rozlišovat, zda se jedná o děti kojené např́iklad na začátku batolecího období, nebo o děti kojené na konci předškolního věku, kdy údajně k tzv. přirozenému samoodstavu dochází (O’Rourke, 2018). Rozdíl mezi těmito dvěma obdobími činí několik let. Dítě předškolního věku má zcela jiné vývojové potřeby než batole a též jeho kognitivní, emocionální i sociální vývoj jsou na kvalitativně velmi odlišné úrovni, takže kojení probíhá ve zcela jiném vývojovém kontextu, přesto v obou př́padech mluvíme o „dlouhodobém kojení“.

Dosavadní výzkumy kojení se zaměřují spíše na benefity kojení hlavně v prvních dnech a měsících života, dopady dlouhodobého kojení zatím nejsou tolik prozkoumány a zůstávají spíše 
na úrovni dohadů (Dowling \& Brown, 2013). Také výzkum zkušeností žen s kojením se soustředí zejména na první měsíce, případně rok života dítěte a ve většině případů se zabývá otázkou, co předpovídá a vysvětluje délku a úspěšnost kojení (např. McInnes \& Chambers, 2008; Mangrio, Persson, \& Bramhagen, 2017). Studií zaměřených na zkušenosti žen s dlouhodobým kojením není mnoho a jak již bylo výše popsáno, za dlouhodobé kojení je ve většině studií považováno kojení nad šest měsíců věku dítěte. „Dlouhodobé“ kojení nad šest měsíců věku dítěte bývá poté prezentováno jako rarita týkající se pouze minoritního počtu žen a vyznačující se tedy jakousi „zvláštnosti““ (Dowling \& Brown, 2013), což může být ovšem diskutabilní. Jak lze vidět ve studii zaměřující se na přehled kojení v evropských zemích (Theurich et al., 2019), kojení dítěte ve věku šesti měsíců se ve většině evropských zemí zapojených do průzkumu netýká pouze minoritního počtu žen, ale stává se poměrně běžným. Ve Velké Británii, v níž ve srovnání s jinými evropskými zeměmi není dlouhodobé kojení tak rozšířené, ženy, které kojily nad šest měsíců věku dítěte, vypovídaly, že právě ve věku dítěte nad šest měsíců začínaly pocit'ovat odpor okolí ke kojení svého dítěte (Tomori, Palmquist \& Dowling, 2016). Ženy uváděly, že zatímco do šesti měsíců věku dítěte je kojení považováno za "správné" a jsou vyzdvihovány jeho benefity, ve věku nad šest měsíců začíná být kojení považováno za "nechutné" a hraničící se "sexuálním obtěžováním” a mají zkušenost s tím, že je od dlouhodobého kojení odrazovali i odborníci (dětští lékaři, gynekologové). Autorky studie ovšem poukazují na to, že ve Velké Británii (i oproti některým dalším evropským zemím) stále kojí poměrně málo žen a kojení nad šest měsíců věku dítěte je ojedinělé (Tomori, Palmquist \& Dowling, 2016).

Velkou část výzkumů na téma dlouhodobého kojení provedla Fairclothová (2010a, 2010b, 2013), která se zaměřila na zkušenosti žen s dlouhodobým kojením v podpůrných skupinách kontaktního rodičovství ve Velké Británii a ve Francii. Tyto skupiny se tvořily v rámci organizace podporující dlouhodobé kojení (La Leche League) a byly s dlouhodobým kojením úzce spjaty. Data získávala pozorováním a rozhovory s ženami, které se hlásily ke kontaktnímu rodičovství a kojily dlouhodobě, přičemž rozpětí věku kojených dětí se pohybovalo asi od jednoho roku do cca šesti let. Fairclothová (2010a) na základě rozhovorů s dlouhodobě kojícími ženami zjistila, podobně jako Dowlingová a kol. (2016), že se tyto ženy setkávají často s odsouzením ze strany společnosti i blízkého okolí a jsou neustále konfrontovány s názory, že to, co dělají "není normální”. Ženy v jejím výzkumu uváděly, že kojí dlouhodobě zejména proto, že se domnívají, že jednají v nejlepším zájmu svého dítěte. Vyzdvihují především pozitivní dopady kojení na vývoj dítěte, a to jak ze zdravotního, tak z psychického hlediska. Ženy, se kterými dělala rozhovory, mají podobný př́iběh - kojení pro ně bylo z nějakého důvodu problematické nebo zažívaly jiné potíže v rané péči o dítě, poté si kojení tzv. "vybojovaly" a nyní setrvávají v kojení a touží po ocenění a schválení od jiných žen. Fairclothová (2010a) uvádí, že je v rámci skupin kontaktního rodičovství dlouhodobé kojení v pojetí těchto žen charakterizováno také obětováním se pro dítě. Podle Fairclothové (2013) byla většina matek v jejím výzkumu rozhodnutá kojit do tzv. samoodstavu, protože to považují za nejlepší věc pro své dítě, která posiluje pouto mezi matkou a dítětem a jako nejlepší volba je založena na "vědeckých důkazech”, což demonstrují „,vědecky podloženými“ myšlenkami kontaktního rodičovství. Nicméně, Fairclothová (2010a) upozorňuje, že benefity dlouhodobého kojení nejsou př́liš prozkoumány a dosavadní výzkumy na toto téma jsou velmi často metodologicky problematické. Autorka si všímá, že právě trend kontaktního rodičovství je tím, co dává ženám přsesvědčení, že dlouhodobé kojení je tím nejlepším, co mohou svému dítěti dát a co navíc 
vyvolává dojem, že se jedná o vědecky podložený př́istup (Faircloth, 2013). Závěry svých výzkumů demonstruje až fanatický př́stup kolem kontaktního rodičovství, kdy jsou ženy např́íklad přesvědčovány, aby kojily za každou cenu a dlouhodobé kojení je pojímáno jako jediná správná cesta, kterou se mohou ženy v péči o dítě vydat, což považuje za určité riziko pro psychické zdraví matek (Faircloth, 2010a). Na druhou stranu, vzhledem k tomu, že v Anglii i ve Francii, kde byly výzkumy provedeny, fungují skupiny kontaktního rodičovství pod organizací La Leche League, což je organizace podporující dlouhodobé kojení, bylo by zajímavé zjistit, jakým způsobem je dlouhodobé kojení pojímáno u žen praktikujících kontaktní rodičovství, které nejsou aktivní v organizacích podporujících kojení, a zda dlouhodobé kojení jako součást trendu kontaktního rodičovství není specifikem jen kontaktního rodičovství ve Velké Británii a ve Francii.

Provázanost dlouhodobého kojení a kontaktního rodičovství potvrzuje i výzkum Thompsonové, Toppingové a Jonesové (2020), které provedly rozhovory s matkami kojícími své děti déle, než do roku věku nebo které měly tuto zkušenost z uplynulých pěti let. Věk kojených dětí se pohyboval od roka až do šesti let věku dítěte. Autorky zjistily, že většina žen $\mathrm{v}$ jejich souboru se hlásila k trendu kontaktního rodičovství. Výzkum byl, stejně jako studie Fairclothové (2010a, b; 2013), realizován ve Velké Británii. Není známo, zda respondentky patřily do skupin podporujících dlouhodobé kojení, respondentky ale uváděly podporu jiných žen ve svém rozhodnutí kojit dlouhodobě jako velmi významnou. Oproti jiným výzkumům na téma dlouhodobého kojení se ve výpovědích žen objevovala témata jako je přenechání odpovědnosti za různá rozhodnutí na dítěti, což spadá do praktik, které zmiňují právě ženy hlásící se $\mathrm{k}$ trendu kontaktního rodičovství např́iklad v České republice (Hanáčková \& Masopustová, 2019). Ve výzkumu Thompsonové, Toppingové a Jonesové (2020) se v souvislosti s dlouhodobým kojením objevuje téma „kojení jako rodičovský nástroj“ a odkazuje na to, že ženy používají často kojení ve výchovných situacích, např́íklad při vzdoru dítěte nebo když dítě prožívá strach nebo bolest. Nicméně toto téma bylo zmíněno spíše okrajově a vzhledem k širokému věkovému rozpětí kojených dětí by bylo vhodné se v navazujících výzkumech zaměřit více na to, jakou funkci plní kojení ve výchově starších dětí.

Do všech prezentovaných výzkumů na téma dlouhodobého kojení byly zahrnuty ženy, které kojily děti v poměrně širokém věkovém rozpětí, pohybující se často od začátku batolecího věku až po konec věku předškolního. Vzhledem k tématům, která se v souvislosti s dlouhodobým kojením objevovala, jako např́klad zvýšené nároky na odpovědnost při rozhodování dítěte nebo používání kojení jako rodičovského nástroje (Thompson, Topping, \& Jones, 2020) a která mohou vypadat jinak u dětí v různých vývojových obdobích, by bylo vhodné se na tato témata zaměřit a pojem dlouhodobého kojení jasněji specifikovat. Dále bylo zjištěno (Dowling \& Brown, 2013), že se dlouhodobě kojící ženy setkávaly často s odporem ke kojení svého dítěte, a to už ve věku od šesti měsíců, tedy ve věku, kdy je dítě stále v kojeneckém období. Autorky výzkumu (Dowling \& Brown, 2013) svými závěry demonstrují nutnost lepší osvěty kojení. Nicméně, výzkum byl proveden ve Velké Británii, kde je procento kojících žen spíše nízké (Dowling a kol., 2016).

\section{Tandemové kojení jako součást dlouhodobého kojení}

Specifickým druhem dlouhodobého kojení je tzv. tandemové kojení, tedy kojení dvou dětí současně, zpravidla se jedná o mladšího a staršího sourozence (van den Berg \& Ball, 2008). 
Tandemové kojení bývá často praktikováno právě matkami, které se hlásí k trendu kontaktního rodičovství (Faircloth, 2010a) a je autory kontaktního rodičovství i zmiňováno jako součást dlouhodobého kojení (Sears \& Sears, 2010). Bryantová (2012) uvádí, že se tandemové kojení používá často proto, aby děti necítily úzkost z dělené pozornosti po narození druhého dítěte. Přestože existuje několik výzkumů zaměřujících se na zkušenost s dlouhodobým kojením, na zkušenost s kojením v tandemu se podařilo dohledat pouze výzkum O'Rourkové (2019), o tandemovém kojení tedy chybí v rámci výzkumů více informací. Tandemové kojení dříve bývalo spíše okrajovou praktikou, která není ve vyspělých zemích príliš rozšířená, v rozvojových zemích, kde jsou intervaly mezi dětmi kratší, je běžnější (Marquis et al., 2012). U mnoha dětí dochází k tomu, že se během následujícího těhotenství své matky odstaví, protože se během těhotenství vlivem hormonální hladiny u většiny žen přirozeně snižuje produkce mléka, a navíc může mít mateřské mléko jinou strukturu a chut', než na jakou je dítě zvyklé (Wambach \& Riordan, 2016). Nicméně, rozšiřující se trend kontaktního rodičovství podporující snahu matek zachovat kojení i během těhotenství s dalším dítětem a po narození sourozence s sebou nese i větší množství žen, které mají s tandemovým kojením zkušenosti (Faircloth, 2013). Mezi odborníky nepanuje shoda ohledně prospěšnosti tandemového kojení a matky jsou často od kojení během těhotenství odrazovány (O’Rourke, 2019).

Jediný výzkum na zkušenost žen s tandemovým kojením je výzkum O’Rourkové (2019), $\mathrm{v}$ rámci něhož byly provedeny rozhovory s celkem třemi ženami kojícími tandemově v USA. Všechny tři ženy měly jedno dítě $\mathrm{v}$ kojeneckém věku a druhé dítě $\mathrm{v}$ předškolním věku. Výsledky jsou prezentovány ve formě krátkých příběhů s slouží spíše jako informační materiál pro ženy, které se rozhodnou kojit tandemově. Autorka uvádí, že se jedná pouze o malý vzorek, který je poměrně specifický - všechny respondentky jsou duly, porodní asistentky nebo laktační poradkyně. Témata nejsou rozvedena do hloubky, a proto autorka poukazuje na důležitost provedení navazujícího výzkumu, který by se týkal tandemového kojení (O’Rourke, 2019). Podle dostupných informací se jedná o jediný výzkum na téma tandemového kojení.

\section{Cíle výzkumu}

Předchozí výzkumy na téma dlouhodobého kojení často zařazovaly do svého zkoumání ženy kojící děti ve velmi širokém věkovém rozpětí, přesto byly všechny považovány za dlouhodobě kojící. Nejasná operacionalizace pojmu „dlouhodobé kojeni““ může být vnímána jako úskalí zejména kvưli tématům, která byla v souvislosti s dlouhodobým kojením předchozími výzkumy identifikována a která mohou být specifická v různých vývojových obdobích dítěte, což je např́klad uplatňování kojení jako rodičovského nástroje (Thompson, Topping, \& Jones, 2020). Specifickým typem dlouhodobého kojení (O’Rourke, 2019) a zároveň praktikou, která je doporučována v rámci kontaktního rodičovství (Sears, 2003), je právě tandemové kojení, přičemž se jedná o oblast, která zatím není výzkumně př́liš podchycena (O'Rourke, 2019).

Prezentovaný výzkum si tedy klade otázku, jakou zkušenost s tandemovým kojením mají ženy hlásící se v České republice k trendu kontaktního rodičovství. Zkušenosti žen kojících tandemově pomohou lépe porozumět nejen tandemovému kojení a zkušenosti žen s touto praktikou kontaktního rodičovství, ale také zkušenosti žen z České republiky s dlouhodobým kojením. Kvůli jasnější operacionalizaci pojmu „dlouhodobé kojeni““ jsou do výzkumu zařazeny ty ženy, které kojí obě své děti, přičemž mladší dítě je v batolecím věku a starší dítě ve věku předškolním. 


\section{METODY}

\section{Sběr dat}

Rozhovory $\mathrm{k}$ analýze byly vybrány $\mathrm{z}$ většího počtu rozhovorů, které vznikly za účelem mapování kontaktního rodičovství v České republice. Ženy byly osloveny přes online skupiny na sociálních sítích. V př́padě zájmu o zapojení do výzkumu jim byl odeslán prvotní dotazník, který se zaměřoval na míru, do jaké se s praktikami kontaktního rodičovství ztotožňují a na základní demografické údaje. Ženy, které uvedly, že se s kontaktním rodičovstvím ztotožňují „plně a jednoznačně“, př́padně „hodně“, byly osloveny s žádostí o rozhovor, který proběhl osobně. Rozhovory byly formou polostrukturovaného interview, přičemž se část otázek zaměřovala na kojení.

\section{Výzkumný soubor}

Výzkumný soubor byl tvořen celkem čtyřmi ženami, které uvedly, že se s principy kontaktního rodičovství ztotožňují plně a jednoznačně (tři respondentky), př́ípadně hodně (jedna respondentka). Všechny ženy uvedly, že provozují tandemové kojení - kojí v současné době obě své děti, přičemž mladší dítě je v batolecím věku (průměrný věk 21,5 měsíců), druhé ve věku předškolním (průměrný věk 4,8 roku). Tři ženy měly vysokoškolské vzdělání (dvě magisterský stupeň, jedna bakalářský stupeň), jedna žena měla středoškolské vzdělání $\mathrm{s}$ maturitou. Všechny ženy byly $\mathrm{v}$ době rozhovoru $\mathrm{v}$ partnerském vztahu s otcem dětí. Jména respondentek byla změněna.

\section{Analýza dat}

K analýze dat byla zvolená interpretativní fenomenologická analýza (IPA), protože se jedná o poměrně homogenní skupinu žen a zároveň o téma, která má explorační charakter a není zatím výzkumně př́liš prozkoumáno, což jsou právě předpoklady pro volbu této analýzy (Smith, Osborn, \& Jarman, 1999). Analýza byla prováděna dle doporučení Smitha a Osborna (2007) postupně pro každý rozhovor zvlášt' a zahrnovala hledání prvotních témat, opakované čtení, rozvíjení nalezených témat a propojování jednotlivých témat u všech př́ípadů dohromady. Klíčové bylo porozumění individuální zkušenosti a její rozvíjení, jako výzkumná otázka tedy byla zvolena otázka, jaké jsou zkušenosti žen praktikujících kontaktní rodičovství v České republice s tandemovým kojením.

Rozhovory byly prováděny a analyzovány jednou z výzkumnic, přičemž s druhou byly pravidelně konzultovány a reflektován byl průběh rozhovorů i analýza. Výzkumnice provádějící rozhovory má sama doma dvě děti v batolecím a předškolním období, nicméně k trendu kontaktního rodičovství se sama nehlásí a tandemové kojení nepraktikovala. Některé praktiky kontaktního rodičovství ve výchově svých dětí sama uplatňovala (zejména nošení dětí). 


\section{ANALÝZA}

\section{Snaha udržet kojení za každou cenu - od útlumu kojení v těhotenství, po prudký nárůst po porodu až $k$ ideálu samoodstavu}

Libuše kojí dvě své děti. Staršímu synovi jsou čtyři roky, mladší dceři budou brzy dva roky. Kojení vnímala Libuše od začátku jako něco, o čem doufala, že se jí podaří a postupně prodlužovala dobu, dokdy bude kojit. „,...kamarádky měly problémy s kojením...tak jsem si ř́kala, jejda, kéž by mi to alespoň tři měsice vydrželo. Pak jsem si řikala alespoň půl roku a pak to najednou tak...se stalo, že jsem kojila rok".

V roce jí přišlo brzy kojení ukončovat, tak kojila postupně déle. Když bylo synovi asi patnáct měsíců, zjistila, že je těhotná. Kojení ale nijak neomezovala a pokračovala v něm dále. I tak ale těhotenství způsobilo, že měla mléka méně a syn se postupně začal kojit pouze na noc, a to jednou nebo dvakrát v noci. Libuše uvádí, že ví, že kdyby chtěla, mohla by syna během těhotenství definitivně odstavit, byla ale rozhodnutá s kojením nepřestávat a směřovat kojení $\mathrm{k}$ tandemu. „. Ano, já jsem věděla...vím, že prostě kdybych chtěla, tak ano, já ho v tom těhotenství odstavím. Ano. Ale já jsem nechtěla. Už to bylo takové....ale prostě ne, nechala jsem to plynout... byla jsem presvědčená o tom, že ten tandem prostě dám “.

Po narození mladší dcery došlo u staršího syna k obratu a k prudkému zvýšení četnosti kojení. „Potom...po porodu, tak to prostě bylo a je doted', že prostě chtěl častěji a byl by nejradši na tom prsu pořád... “. Libuše kojila nejdřív obě děti dohromady a postupně to začala střídat, nyní kojí většinou děti odděleně, s tím, že každé dítě má jedno prso. „Jako já jsem je ze začátku kojila naráz...ze začátku to šlo. Pak teda jsem se to pokoušela střidat. Třeba při tom usínání to pomohlo. To jsem si vzala $i$ to miminko a i jeho...ale ted' už minimálně. Pak to teda méli rozdělené no. Automaticky se to tak stalo. “. Libuše popisuje jako svůj ideál se dostat k samoodstavu, zároveň zmiňuje, že je to sice lákavá představa, ale zároveň pro ni náročná a že se podle ní starší syn odstaví, až se odstaví mladší dcera. „,No, líbí se mi myšlenka jakoby toho samoodstavu. Tak jako... uvidíme. Je pravda, že ted' treba ted' už u toho syna...no, jako nevím, ten se podle mě neodstaví....podle mě se odstaví, až se odstaví ta mladši “..

Alexandra kojí staršího syna, kterému jsou tři roky a devět měsíců a mladší dceru, které je rok a dva měsíce. Alexandra kojila dvouletého syna i během těhotenství s dalším dítětem, nezaznamenala nižší množství mateřského mléka, ale i tak u syna docházelo k útlumu kojení před narozením dcery spával celou noc bez buzení na kojení a přes den se kojil pouze ve „vypjatějších situacích“, po narození dcery došlo ale k prudkému nárůstu kojení, kdy se starší syn začal kojit více než mladší dcera, což trvá doted'. ,.. přes den se opravdu kojil jen při nějaké vypjatější situaci a....od té doby, co se dcera narodila, tak se koji furt...několikrát denné, několikrát v noci, prostě víc než mladší dcera....".

Tandemové kojení funguje u Alexandry tak, že se kojí většinou obě děti zároveň, přičemž každé z dětí má své prso. „Já to totiž ještě jako mám rozdělený, ty prsička, že každej má jedno“. Alexandra by chtěla směřovat k samoodstavu. ,Tak jakoby já jsem určitě fanouškem toho prirozeného samoodstavu. To tedy doufám, že se tak stane“. Jediná situace, ve které si dokáže představit, že by kojení omezila, je třetí těhotenství. „, Jako kdybych třeba otěhotněla potřetí, tak bych to možná zvažovala, tak to jo...ale to je asi takové to jediné, co bych zvažovala...nebo jako kdy by to pripadalo vúvahu. “ 
Marika kojí dva syny, staršímu jsou dva a půl roku, mladšímu čtyři a půl roku. S kojením neměla Marika nikdy problémy a už od porodu prvního dítěte jí šlo kojit snadno. Otěhotněla, když bylo staršímu synovi něco kolem osmnácti měsíců. $\mathrm{V}$ té době došlo již $\mathrm{k}$ výraznému útlumu kojení. „,Tobík už skoro necucal...v podstatě jako sem se musela dost snažit, aby se neprestal kojit úplně. " Po narození druhého dítěte ale potřeba kojení staršího dítěte výrazně stoupla. „No, von pak chtěl bejt na tom prsu furt...furt, tak sem je prostě jako kojila voba dva zároveň a je to tak i ted', jako nijak to nevomezuju a ani sem to nedělala. “

Nyní tedy kojí Marika obě děti dohromady. Uvádí, že každý má své prso. Jejím ideálem je samoodstav, ke kterému by chtěla dojít a domnívá se, že u staršího syna k němu již částečně dochází, protože kojení „přestává umět“ a kdyby tady nebylo mladší dítě, tak by se starší podle Mariky už kojit přestal. ,, , no tak on v podstatě podle mě už začiná (pozn. samoodstav)....kdyby tu, kdyby tu nebyl ten Adámek, tak jako si myslím, že kdyby nebyl Adámek, tak si myslím, že si na to ani nevzpomene“.

Leona kojí dvě dcery. Mladší dceři jsou necelé dva roky a starší dceři necelé čtyři roky. Leona mluví o výrazných problémech s kojením starší dcery, které měla po prvním porodu. „No, kojení byl jako děs....musela sem hrozně, hodně, bojovat, at' to zvládnu..zvládnem. "Situace se stabilizovala asi v osmi měsících starší dcery, kdy se rozkojila naplno. V roce a čtvrt starší dcery ale zjistila, že je těhotná a problémy s kojením se objevily znovu. „Ehm...Lucka, tak nějak, prostě prestala prso chtít... asi tam bylo málo mléka, nevím vi̊bec. Prostě byly jsme tam, kde na začátku. "Leona se snažila kojení udržet, starší dceru na doporučení laktační poradkyně i v noci budila a kojila ji v polospánku, aby se jí stimulovala tvorba mléka. „ׁ̌íkala sem si, no, že prostě když už sem do toho dala tolik...tak...tak jako nebudu přstávat po pár měsících, kdy to bylo jako v klidu a kdy to šlo. Byla sem z toho ale kolikrát tak unavená a votrávená... a navíc to dost bolelo... asi jak toho mléka nebylo moc, nevím. "

Kojení se jí nakonec podařilo udržet během celého těhotenství a po porodu, který proběhl ambulantně (z porodnice odešla po několika hodinách), začala kojit současně starší i mladší dceru, přičemž starší projevovala o kojení zájem větší než kdykoliv předtím. ,No a u Lucky se to konečně pořádně rozjelo... vlastně sem toto nikdy nezažila, takové její dychtění po kojení a ten zájem. Až po porodu Marušky. “ Doted’ přetrvává vyšší frekvence kojení starší dcery. Mladší dcera má pouze pravé prso, starší má primárně levé, ale po dokojení mladší sestry „dopije“ i pravé prso. Leona by si přála dostat se až k samoodstavu u obou svých dcer. „Když už to byl takový...no, boj ...ze začátku..i v tom těhotenství pak...tak, tak to doklepu až do konce. “

\section{Matka uprostřred - „Přripadám si, že jsem pořád ... pořád mezi dětma...fyzicky a psychicky...uprostřed"“}

\section{Averze vioči staršímu dítěti a následná bagatelizace negativních pocitů - „někdy je to celkem nervák...ale musíš to vydržet"}

Téma, které se týkalo negativních pocitů u matek během tandemového kojení, se objevovalo velmi často, a to ve třech rozhovorech, pouze $\mathrm{v}$ př́ípadě Alexandry toto téma nijak zvlášt' nevystupovalo. Prožívání Libuše a Leony probíhalo v podobné trajektorii, zahrnující 
nepř́ijemné pocity v těhotenství a poté averzi při kojení vůči staršímu dítěti po porodu. $\mathrm{O}$ averzi po porodu mluvila také Marika.

Libuše a Leona zmiňovaly nepř́jemné pocity během kojení v těhotenství, obě s tím, že kojení ukončovat nechtěly i přes tyto nepř́ijemné pocity. „...jako, nebylo to bolestivé, jak někdo popisuje...jako dalo se to. Spíš mně to bylo nepř́jemné. Prostě nepř́ijemné no. Ale jako nechtěla jsem to ukončovat".

Po porodu zmiňují Libuše, Marika a Leona, že začaly cítit averzi vůči staršímu dítěti. „,Tak jsem...tak to bylo takové a což mě prekvapilo, o čem se nemluví moc, po tom porodu...tak...tak...taková ta averze vi̊či tomu staršímu “. Samy si tuto averzi vysvětlují tím, že měly pocit, že starší dítě „krade“ mléko mladšímu, že na kojení „nemá nárok“. „,Prostě...no, vnímala sem ho jako...no, jako zloděje. Zloděje mléka. “; „, Prostě to bylo ve mně no....prostě ty už jsi velký, ty už na to jakoby nemáš nárok.. “. Marika zmiňuje, že u ní averze vůči staršímu přišla asi jako reakce na to, že měla jiné představy o tom, jak to bude vypadat po porodu. „,...jsem měla jako jinou predstavu. Myslela sem, že von si bude hezky hrát s kostičkama u mých nohou a já si budu v klidu kojit toho mladšího. Prostě....prostě ta predstava byla jako úplně jiná no “. Marika si představovala, že bude v klidu kojit mladší dítě a starší si bude hrát, ve skutečnosti měl ale starší syn spoustu požadavků, chtěl se kojit víc než mladší dítě, často plakal, začal se v noci velmi často budit apod., což podle Mariky vyústilo až ve výraznou averzi vůči staršímu dítěti. Podobně si averzi vysvětlují i Libuše a Leona, které jako Marika popisují změnu v chování staršího dítěte (větší potřeba kontaktu, kojení, mnohem častější frekvence buzení v noci, neklid, větší závislost na matce), jejich snahu vyhovět potřebám staršího dítěte a následnou averzi vůči staršímu. ,, Tak moc jsem mu chtěla vyhovět...vnímala jsem...jsem, že to potřebuje, chce, ale zároven̆ mě tím tak strašně vysíral...no, averze prostě jako vyšitá...jsem si s tim vůbec nevěděla rady“; „A ještě teda v tom šestinedělí, tam to teda bylo náročné. Já už jsem třeba nemohla, fyzicky, psychicky, užjsem ho nemohla kojit, tak jsem se ho snažila alespon̆ přitulit...ale on brečel samožrejmě. Brečeli jsme vlastně oba no. Někdy jsem na něj byla...no...i trošku nepř́ijemná...na což teda nejsem úplně pyšná...jako nechci řict až agresivní. ". Libuše, Marika i Leona hodnotí prožívání po porodu jako velmi náročné, hraničící až s jejich totálním vyčerpáním. Libuše i Leona popisují výraznou touhu „dát starší dítě pryč“. „Zatímco ten starší, toho bych prostě chtěla...chtěla jsem ho prostě dát někam pryč no. A ne ho kojit. Takže to šestinedèlí, to bylo náročné".

Přestože všechny tři ženy mluvily o pocitech averze vůči staršímu dítěti zejména v období šestinedělí po druhém porodu, všechny tři zmiňují, že nějaká část těchto negativní pocitů stále přetrvává (,, se snažím no ...ale někdy je to celkem nervák pořád“). Marika tyto pocity označuje jako „divné“. „, A potom třeba ted’ka občas od Tobika jakoby strašně lechtá [pozn. kojení]. Jako je to takový...divný no". Leona říká vyloženě, že je jí kojení staršího dítěte mnohem méně př́jemné než kojení mladšího. „,To kojení staršího děcka...je takový...nepř́ijemný už prostě. Nepřijemnější....než když kojím mladši. " Libuše zase zmiňuje, že v ní přetrvává část pocitů vzteku vůči staršímu dítěti, protože má pocit, že „starší dítě už odkojila“ a ted” je „na řadě“ mladší dítě. Ženy si to vysvětlují tím, že jednak je kojení starších dětí jiné fyzicky (,,Prostě ten tah je jiný...silnějšsí. No, taky tam jdou cítit dost ty zuby. Jako...není to nic hrozného. Takže...jako je mi to, ano, je mi to mín př́jemné no, než prostě u té dcery. Psychicky je prostě horši kojit jeho, než.. než dceru no "), jednak také tím, že se starší děti u všech tř́i žen chtějí kojit více, než mladši dítě, přestože jsou všechny starší děti již v předškolním věku ,....se kojí vic, než ta 
mladší....prostě je na mně furt, i ted', furt to prso chce...což už je prostě taky takový...takový jakoby náročný no, pořád držet to tempo “.

Libuše, Marika i Leona zmiňují negativní pocity vůči staršímu dítěti, někdy společně s myšlenkami o tom, že by se starší dítě ,již kojit nemělo“, že „,bere mléko mladšímu dítěti“ a že na kojení „nemá nárok“. Většinou po popisu takových pocitů a myšlenek následuje určitá bagatelizace pocitů (,, ...ale jako neni to nic hroznýho...dá se to vydržet... “; ,, ...jsou horší věci na světě “; ,...prostě to ted'kon tak je, musíš to vydržet“; „. A musím si řikat, že prostě není ještě úplně tak velký no, jak, jak...jak mi to to podvědomí prostě asi trochu řiká ") a shazování pocitů a myšlenek (,,Ale jako vím, že je to blbost"; ,, ...jako to je hloupost, ale napadne mě to “; „ř́kám si, ježíš...jseš blbá, myslet na takový věci. “). Také se samy podporují v tom, aby v kojení tandemu nepřestávaly, což vždy zmiňují právě v popisu prožívání negativních emocí. (,,jako...si řikám, to dáš. Dáš to ten tandem. “; „, Ale prostě ríkám si, kojišs obě děti, tak prostě to tak je. Je to tak. Je to pro ně to nejlepší, co mưžeš udělat"; „,Vybojovala sis to, tak bojuj dál").

\section{Potřeba nastavit si hranice - „Neměla jsem sílu dávat hranice...nešlo mi to a nefungovalo to"}

Všechny čtyři respondentky zmiňují $\mathrm{v}$ rozhovorech téma nastavování hranic. U všech se objevuje téma snahy o regulaci kojení, a to pouze u staršího dítěte, mladší děti kojí všechny ženy zatím stále tzv. „,na požádání“. Libuše mluví o tom, že kojí staršího syna na požádání (a kojení tedy nereguluje), jen pokud je na tom psychicky dobře (,,Snažím se. Pokud to můj psychický stav dovoluje...naplňovat opravdu jejich potřeby kojeni tak, jak to aktuálně potřebuji. “). Dále zmiňuje své „psychické vyčerpání“, které je podle ní z části zapříčiněn velkou frekvencí, se kterou by se chtěl starší syn kojit (,, A nastavili jsme pravidla. Prostě on chtěl hrozně moc... to pak přispívá, no, k tomu mojemu jakoby vyčerpání... psychologickému“").

O nutnosti regulovat kojení staršího dítěte kvůli „neustálým požadavkům“ na kojení mluví i Leona (,,neustále má ty své požadavky na prso, na kojení...proto jsem s tím musela něco udělat ...nebo respektive snažila jsem se"). Podobně jako Libuše, i Leona zmiňuje, že její snaha naplňovat požadavky na kojení staršího dítěte ji negativně psychicky ovlivňovala (,starši pořád na prsu...někdy jsem z toho fakt šilela. Pořád, pořád, pořád. “). Alexandra kojení reguluje někdy ve smyslu délky kojení, která jí už není příjemná (,,Nebo třeba...u toho staršího...ted' jakoby je to, že on má ted’ nějaký potřeby, kdy prostě si cucá a dudá hodinu a prostě má to rád... a toho prostě už mi jakoby není...no, není mi to tak dlouho př́jemné. ") a také kvůli mladší dceři, kterou potřebuje hlídat, což se s více než hodinovým kojením staršího dítěte vylučuje. Co se týče četnosti, i staršího syna kojí na požádání, tedy kdy chce (,,Dostane, kdy chce, ale jakoby trochu už omezuju tu délku, takže to prostě musím omezit z praktických di̊vodi̊, jinak bych prostě musela být chobotnice. Ale jinak jako v pohodè. Prostě kdykoliv chce, ale omezuju tu délku. ").

Marika, podobně jako Alexandra, kojí obě děti na požádání. O regulaci kojení př́íliš nemluví, zmiňuje ji pouze ve dvou prŕpadech, a sice, když si z toho děti začnou dělat legraci (,Ale...jakoby jsou tam $i$ takový ty..kdy jim prostě řknu, ale ted'kon už dost. Už mě to teda...nebo když si začnou třeba z toho dělat legraci a různě ty prsa tahaj nebo je votáčí. ") nebo na veřejnosti ve společnosti lidí, u kterých ví, že jim kojení vadí (,, Tak..tak to je mně třeba jako protivný no. Když jsou třeba lidi, o kterých vím, že jim to vadi. “). 
Mezi způsoby, jakými hranice nastavují, patří zejména domluva s dítětem (,,No, jako já se jim to prostě snažím vysvětlit no. ") a nabídnutí nějaké alternativy, například obyčejného mléka z lednice (,Jako ted' někdy, když chce mlíčko, tak mu nabídneme mlícko z lednice no. S tím přišel někdy před rokem manžel, že mu ř́ká, a nechceš mlíčko z lednice? Tak to se tak ujalo no. Takže prostě si dá to mlíko, protože ho má fakt rád. Takže někdy to klapne, někdy si dá to mlikko a je spokojený. “). Libuše zmiňuje, že požadavky na kojení někdy „vyšumí“, pokud musí dítě počkat (,A někdy třeba to vyšumí, že usne...taky jsem se snažila...jako říct mu počkej, ted' si dá miminko, to někdy teda pomůže.. ").

Marika uvádí, že v případě, kdy ví, že bude ve společnosti lidí, kterým kojení vadí a bude tedy muset kojení regulovat, nastavuje hranice tak, že si na sebe bere oblečení ztěžující dětem se dostat k jejím prsům (,,...tak si vezmu na sebe prostě něco, co je složitějši pro ty děti. Třeba jako dvě vrstvy nebo tak, prostě něco, kde se tak lehce $k$ těm prsoum nedostanou. Aby je to prostě trochu zabrzdilo no. Jinak bych je tam méla furt. ").

To, jak děti hranice akceptují, je u všech respondentek velmi proměnlivé. (,,Každý den to je jinak...někdy v pohodě, někdy vůbec a nepomůže nic, jen prso. "), př́padně zmiňují, že děti hranice chápou, ale zatím je úplně nerespektují (,,Jako ted’kon už mu to třeba řeknu a on to pochopí...nebo ne že by to úplně respektoval, ale jako už se nějak domluvíme. "). Leona a Alexandra si to vysvětlují tím, že nejsou v nastavování hranic striktní a dělá jim problémy na nastavených hranicích trvat (,,Já se přiznám, že teda úplně nevím...jako já nejsem taková ta úplně striktní...na ty pravidla...což je chyba, možná teda není...no, každopádně, prostě nejsem úplně taková, že bych řkla, prostě v téhle situaci ano, v téhle třeba už ne. ").

\section{Vnímané nevýhody tandemového kojení, které se matky „snaží nevnímat“}

Respondentky byly tázány, zda vnímají nějaké nevýhody tandemového kojení, př́ípadně co jim samotným připadá problematické. Všechny ženy popisovaly stav, který Leona označuje jako nutnost být „mezi dětma“ („Připadám si, že sem pořád ... pořád mezi dětma...fyzicky a psychicky...uprostřed“). Podobně to popisuje i Marika (,Jako já mám všechny nočni košile úplně rozervaný...voni jsou takto na mě voba a prostě se každý kojí z jedný strany...jsem prostě takto uprostřed... Takže to jediný je jako hrioza.... "). Libuše zmiňuje výraznou závislost dětí na ní, což znamená, že děti nemohou jít např́klad na noc k babičce (,,Oni mají prostě takové maminkovské období...ted' to je prostě i pro mě no. No, takové jakoby náročnější to období. Prostě maminka, maminka. My nikam od maminky nepůjdem. “), podobné je to u Leony (,„Jsou pořád samé máma, máma no....ale jakoby, no, jsou na mně dost závislý. Což jakoby není špatně no. “).

Alexandra zmiňuje, že právě potřeba dětí, aby byla mezi nimi a byla jim k dispozici, vede $\mathrm{k}$ tomu, že musí odcházet od manžela a vrátit se mezi děti, což ji mrzí (,, tak to je jediná věc, která mi ohledně toho tak nějak vadí...nebo mrzí, je to, že...že...spím mezi nima pořád. Jak já je v noci ještě kojím oba, tak já jsem nevymyslela žádnej jinej způsob, jak to udělat, aby se nemlátily, nekopaly, když se domáhaj k prsíčku, takže to je jediný, co mě mrzí. Já se vždycky přitulím, skoro usnu a pak musím odejít mezi děti...zpátky no. “). Dopady na čas strávený s manželem uvádí i Libuše (,Někdy si jako řikáme s manželem, a kdy teda...a kdy teda budeme moct no. Kdy teda...jít spolu třeba někam sami no. Nějaký výlet třeba...třeba sami dva."). Kromě dopadu na čas s partnerem zmiňují ženy, že nemají př́liš času samy na sebe, což vede k únavě (,někdy teda melu...z posledního“). 
Podobně jako u vlastních negativních pocitů, i tady respondentky zmiňované nevýhody bagatelizují nebo si je snaží „,nepřipouštět“ (,,I když jako já kolikrát ani nechci no...nechci (pozn. být sama s manželem), protože by mi prostě chyběly ty děti no. “; ,prostě ne, že bych si potřebovala odpočnout. Jako někdy jo, no, někdy potřebuju, ale prostě snažím se to tak nevnímat"; ,.. Tak, tak si řeknu...jo. Ale vždycky to pustím z hlavy. Ale napadne mě to někdy (pozn. o př́lišnné závislosti dětí na ní) “.). Např́íklad Libuše zmiňuje únavu a pocit, že jsou na ní děti moc závislé, ale ukončuje to tím, že žádné nevýhody nepocit’uje (,,Toto teda byla teda taková věc...žádné nevýhody to ale nemá no. Nemá. “).

\section{Tandemové kojení jako jistota pro starší dítě v novém uspořádání rodiny a snaha matky o podporu sourozeneckých vztahů}

\section{Kojení jako jistota, nástroj $k$ uspokojování potřeb a regulaci chování dítěte po narození mladšího sourozence - "hledá jistotu, když se mu nabořila tím...novým dítětem"}

Velkým tématem, které se objevovalo u všech respondentek, bylo téma reflektující změny v kojení zejména staršího dítěte. Respondentky samy od sebe $\mathrm{v}$ odpovědích př́liš nezdůrazňovaly mladší dítě a více mluvily o starším dítěti a jeho potřebách, proto i zde bude věnováno více prostoru staršímu dítěti.

Jak již bylo nastíněno v tématu vývoje tandemového kojení, starší děti přirozeně samy od sebe tlumily svou potřebu kojení před narozením prvního dítěte, během těhotenství matky, což mělo vliv na lepší spánek i na to, že děti již vydržely bez matky delší dobu. V př́padě všech respondentek došlo po porodu $\mathrm{k}$ tomu, že se starší dítě začalo chtít mnohem více kojit, než předtím a často i více, než mladší dítě ("...no, takže on se prostě vod toho porodu kojí nejen $v$ noci častěji než dcera, prostě potřebuje to ujištěni mnohem více, ně̌ předtím, takže to je hrozně zajímavý"), což je opět doprovázeno častějším buzením v noci ("Protože ten starši se teda začal po porodu víc budit no"). Respondentky si tuto potřebu dítěte vysvětlují tím, že dítě "hledá jistotu" ("Tak to šlo vidět, jak vlastně pořád chtěl to prso...to kojení...že hledá jistotu, když se mu nabořila tím...novým ditětem, no”). Větší potřeba kojení přetrvává u všech starších dětí stále ("Ale ted' je prostě takový pořád ještě, no, asi je to jen období, ale prostě že potřebuje ten kontakt”), což si respondentky vysvětlují opět jako ujišstování o dostupnosti matky (“...tak aby prostě věděl, že jsem dostupná...že je dostupný to moje prso, pro něj””) v rámci nového uspořádání rodiny, do které nyní patří i mladší sourozenec dítěte ("A já nevím...je to doted". Nevím, jestli je to tím, že tam je to miminko nebo co, jako ten vetřelec... protože on sám ríkal, mličko, mličko od mámy, chci to mličko").

Samy respondentky označují kojení starších dětí jako “emoční” nejen ve smyslu překlenutí období narození mladšího sourozence, ale také v kontextu celkového prožívání dítěte. Zdůrazňují, že již plní primárně vztahovou funkci ("protože oni teda sosaj oba, ale je to spíš takový prostě už jako...no spíš jako kontakt, klidový...má to už hodně tu vztahovou funkci.”). Všechny respondentky uvádí, že děti vyhledávají kojení ve vypjatých, emočně náročných situacích, při bolestech, konfliktech, vzteku dítěte nebo strachu ("když na něj něco leze, kdyžje naštvaný, když třeba zuby, když má takový jako ty... když je smutny'”; “Ale ted', čím je ten syn starší, tak je to mnohem víc o té emočni potřebě. Takže jakoby spadne na hřišti, jde se nakojit...rozbije si koleno a dá si prsičko"; "Prostě ve vypjatějšsich situacích, když jsou 
nejistí...nebo jako nemusí to být ani nepř́jemný, třeba se jenom stydi”;; “...jakoby i když má nějaký konflikt, třeba s dítětem na hřišti, ”). To, že jsou schopné dítěti kojením uspokojit velkou škálu emocí a zklidnit množství problematických situací, označují jako důvod, proč s kojením stále pokračují ("Prostě je to o tom vztahu, jinak bych čtyřletého nekojila”; "no v podstatě je to jakoby moje...moje taková zbran̆ to kojení...když nevím, co dál..jinak bych teda už asi to, nekojila").

Marika mluví o tom, že kojení staršího dítěte jí pomohlo překonat období po narození mladšího dítěte. Zmiňuje, že s prríchodem nového dítěte do rodiny se starší syn začal chovat problematicky, což pro ni bylo náročné a nezvládala s ním tyto věci probírat (,,Hlavně že jsem jako, no, furt jemu vysvětlovat něco, že to nejdř̀v musí takhle.... že jsem se prostě na to vykašlala a nechala jsem tomu volný průběh prostě “). Východiskem ze situace bylo kojení staršího dítěte (, A já, jak jsem třeba kojila Adámka...a von si stoupl $k$ hlavě a řval prostě, takže potom mi prostě přišlo jako nejlepši mu zacpat tu pusu tím prsem a bylo to. "). Podobnou situaci popisuje i Leona, jejíž dcera začala po porodu své mladší sestře ubližovat, odmítala ji a žárlila na ni (,, bylo to hrozně náročný...malá měla úplnej kolaps “), Leona nevěděla, jak se situací naložit, protože nezvládla trvat na nastavených pravidlech (,ty pravidla jsem sama nedávala") a zjistila, že místo nastavování pravidel funguje dceři nabídnout prso (,, takže prostě pravidla šly pryč, hranice jsem neřešila no...místo toho jsem začala dávat to prso... bylo to jednoduchý takto").

\section{Sourozenecké vatahy jako motivace k tandemovému kojení - “... hlavně aby nebyla žádná změna"}

Důvody, pro které se rozhodly respondentky kojení ponechávat i u starších dětí, byly zmíněny $\mathrm{v}$ rámci minulého tématu. U Leony a Libuše se ale objevilo specificky reflektování těch důvodů, proč které se rozhodly kojit tandemově, tedy současně obě děti. Alexandra a Marika nesdělují, že by se pro tandemové kojení rozhodly záměrně a spíše to vyplynulo ze situace. Leona i Libuše naopak uvádějí, že již před narozením druhého dítěte měly plán kojit tandemově ("ten tandem byl prostě rozhodnutí...rozhodnutí kojit oba, ke kterému jsem došla ještě pred druhým těhotenstvim").

Hlavním důvodem, který Libuše i Leona uvádějí jako klíčový ve svém rozhodnutí kojit děti tandemově, je podpora vztahů mezi sourozenci. Leona sděluje, že sama měla se svou sestrou problematický vztah a chtěla by, aby vztah jejích dvou dcer byl jiný, čehož by mohla dosáhnout právě tandemovým kojením ("chtěla sem, aby to bylo jiný mezi nima...proto mně ten tandem jako takový prišel super”). Libuše také mluví o vztazích mezi sourozenci, které jsou pro ni velmi důležité, s tím, že neví, do jaké míry to ona sama může ovlivnit, nicméně tandemové kojení by jí v tom mohlo pomoct ("Bylo to prostě pro mě dưležitý, aby teda...aby prostě ten vztah měli no. Hodně, hodně důležité. A vlastně chtěla bych...nevím, nakolik to můžu já ovlivnit, tim tandemem snad jo...snažím se, prostě aby to tak méli pořád no.").

Obě respondentky vysvětlují, že se domnívají, že tandemové kojení pomůže ve vztahu sourozenců proto, že díky přetrvávajícímu kojení příchod nového dítěte do rodiny starší dítě tolik nezasáhne (“, já jsem hlavně chtěla...aby nástup toho miminka, aby ho to prostě co nejmín zasáhlo no") a také nebude mít starší dítě pocit, že mladší dítě "nastoupilo na jeho místo" ("Takže to byl vlastně ten dưvod. Prostě aby to miminko nenastoupilo na jeho místo no. Prostě ano, tak”). 
Libuše zdůrazňuje, že pro ni bylo velmi důležité a vnímala to jako důležité i pro vztah mezi dětmi, aby po porodu mladšího sourozence nedošlo $\mathrm{k}$ žádné změně v rámci rodiny ("Žádné změny jsme nedělali no. Prostě ale nejen to kojení... Prostě hlavně aby nebyla žádná změna. To bylo nejdůležitější.”).

\section{Rozhodnutí na dětech - “...jako přijde jako nejideálnější, když to prostě napadne jeho, že jo. Já ho přemlouvat nebudu”}

Výpovědi všech čtyř respondentek prolíná téma nechávání odpovědnosti na dětech. Tedy to, že respondentky považují za důležité, aby se děti v klíčových věcech rozhodovaly samy a zastávají partnerský př́stup s dítětem ("Tak jakoby prostě to ditě jako partner. Snažím se k němu pristupovat jako $k$ dospělému...”). S tím souvisí i směřování u všech čtyř žen k přirozenému samoodstavu v kojení. Marika vysvětluje, že zkoušela kojení omezovat, což se nepodařilo, proto jí prrijde jako nejlepší varianta, když to syna samotného napadne ("..jako než já abych to utínala jako já, což jsem už třeba několikrát zkoušela, protože mi to třeba bylo nepříjemné nebo tak a naprosto to nešlo, tak mně jako prijde jako nejideálnější, když to prostě napadne jeho, že jo. Já ho premlouvat nebudu.”). Podobně se vyjadřuje i Leona (“...stejně nevim, jak bych to dělala. Tak at'si to rozhodne sama").

O odpovědnosti, kterou nechávají na dětech, vypovídají respondentky nejen v souvislosti kojením, ale s př́stupem ke svým dětem obecně. Linda tak vysvětluje, proč jí děti zatím nikdo nehlídá ("Ale jako, toto já nechávám na nich. Já prostě...prostě nechci, nechci je někam tlačit. Nechávám, at' si to rozhodnou sami”). Alexandra se tímto př́stupem staví k odmítání jídla u staršího dítěte (“...určujou si, co chcou jest, nevadi mně, že prostě nechcou jest...nenutím, prostě nenutím do nich jídlo. Prostě když jim to nechutná, tak nepotřebuju, aby to jedli. Jako kvůli mně, to nepotrebuju.").

\section{Podpora i kritika tandemového kojení vedoucí k upevnění přesvědčení}

Posledním výrazným tématem, které se v rámci výpovědí respondentek objevovalo, bylo okolí žen, zejména reakce okolí a vliv, který to na tandemové kojení mělo.

\section{Necítit se „divně “ díky podpoře}

$\mathrm{O}$ nějaké formě podpory a důležitosti v rozhodnutí kojit tandemově mluví všechny čtyři respondentky. Libuše zmiňuje podpůrnou skupinu kontaktního rodičovství, na kterou narazila náhodou a díky které se začala o tandemové kojení zajímat ("A člověk se tam dozví.. se dưležité věci...třeba téma to tandemové kojení. To na mě mělo velký vliv."). Vypovídá o tom, že skupina žen, které to "měly nastaveno stejně", ji vedla k pocitu "normálnosti" a utvrzovala ji v tom, že "dělá správně" ("Prostě jsem se setkala s těma lidma, co to mají stejně jako já a to je pro mě fajn....připadala jsem si normálně tam......už vlastně neznám ani jiné. Prostě mně to přijde normální. Spíš prostě jsem někdy prekvapená, že to někdo má jinak. Díky nim vím, že to dělám tak jako, no, správně.”). O skupině žen, které mají podobné smýšlení, mluví i Marika, která zmiňuje, že si díky tomu, že se stýká s podobně smýšlejícími ženami, nepřipadá “divná” a cítí podporu pokračovat v "cestě, kterou se vydala" ("já asi žiju v sociální bublině. Protože když se jako někde takto sejdeme, tak za chvilku máme všechny prsa venku a kojíme. Ale to je jako tim, že jsme asi v nějaký podobný bublině...to je taková podpora jakoby pro mě, to mně pomáhá 
necitit se tak jakoby...divná...nebo divně, na té cestě, kterou jsem se jakoby vydala”). Leona mluví o tom, že se s ní přestaly stýkat některé kamarádky. Uvádí ale, že jí to nevadí, protože si našla jiné, které ji chápou a podporují, protože to samy mají velmi podobně (,,Mrzelo mě to jakoby, ne že ne, jo. Ale takový je život...obklopila jsem se lidma, co to mají prostě stejně“).

Mezi dalšími podpůrnými faktory byla zmíněna rodina, konkrétně prababička Alexandry, která ji chválila pokaždé, když ji viděla kojit obě děti zároveň ("a když jako pochybuju, tak si vzpomenu na babi...jak mně vždycky řekla, dobře to dělás””). Marika zmiňuje zejména podporu laktační poradkyně, která za ní po porodu přijela a pomohla jí, si tandemové kojení "dovolit" ("Já jsem ji kontaktovala, aby mně jakože...ona za mnou přijela, to bylo úplně super, asi druhý týden po porodu ke mně přijela a mně jako...mně docela pomohla v tom směru, jako si dovolit...si dovolit ten tandem."). Marika kromě toho zmiňuje i podporu své gynekoložky, se kterou se nebála věci ohledně tandemového kojení konzultovat, protože věděla, že ji neodsoudí ("Ona je naprosto skvělej člověk. Kdyby ona nebyla taková osobnost, který bych si to troufla ríct, tak v podstatě bych jí to neřekla. (...)Tušila jsem naprosto, že mě nebude jako rešit).

\section{Kritika tandemového kojení, která vedoucí k upevnění postojů - “at’ si říkaj, že jsem divná, dělám si, co chci”}

Tématem, které se objevuje u všech žen zahrnutých do výzkumu, je konfrontace s nesouhlasem okolí k tandemovému kojení. Nejčastěji jsou zmiňováni členové širší rodiny. Alexandra uvádí, že její tchán byl během rodinné oslavy tak rozčilený, že kojí obě děti, že je důrazně požádal, aby odešli někam jinam (,, To byla hodně jakoby vyhrocená, no, situace....tak sem šla, ale šlo vidět, že se fakt nasral, když sem vytáhla prsíčka a vobě děti si vzala"). Podobnou zkušenost uvádí také Leona, podle níž je její kojení obou dětí v rámci rodiny tabu, nesmí se o něm mluvit před jejími rodiči ani před rodiči partnera (,Nemluvíme o tom. Nikdy. Déláme, že se to neděje. "). Libuše zase uvádí, že u nich v rodině se o kojení obou dětí mluví hodně, přičemž je od něj důrazně odrazována (,„Pořád řikají, nech to mličko mladšímu, vždyt' ten starší...no.. vypije mu to..to není normální...no, to co dělám asi“). Odborníky v této souvislosti zmiňuje pouze Marika, která zažila na oddělení šestinedělí po porodu mladšího dítěte, když se chodil kojit i starší syn, údiv ze strany sestřiček a odrazování ze strany lékařù (,,Voni se chodili na mě divat jak na atrakci takovou jako. Sestřičky teda neřekly nic, no doktoři s tim měli problém a pořád maj, co tak vim od kámošek...mně řikali furt dokola, že mám regenerovat, nabírat sílu po porodu a snažit se to jakoby dobrý mliko dát malýmu a ne tomu staršímu. ").

Marika sděluje, že si o ní jejich známí vykládají, že je „divná“, nicméně pro ni je to jen signálem, že by si měla stát více za svým (,At’si řikaj, že jsem divná, dělám si, co chci.... a budu si za tím stát "). Všechny ženy mluví o tom, že právě odpor k okolí a odrazování od kojení obou dětí je vede $\mathrm{k}$ silnějšímu přesvědčení, že dělají dobře a že by se neměly na okolí soustředit (,Každá jejich jedovatá poznámka mi dává sílu...sílu bojovat...za sebe a za svoje přesvědčení. “). Libuše, Alexandra a Leona v souvislosti s kritikou tandemového kojení zmiňují, že se jim dostává kritiky zejména kvůli staršímu dítěti, které je v předškolním věku. Kojení mladšího dítěte, tedy dítěte v batolecím věku, nikoho z okolí nepohoršuje (,, ...přitom mladšiho vi̊bec neřěsej “; , To kojím furt (pozn. mladší dítě) jako pred nimi v pohodě, to nikoho nezarazí, ale jak se přidá starší, no jako... je peklo“). 


\section{DISKUZE}

Cílem prezentovaného výzkumu bylo popsat zkušenost s tandemovým kojením u žen hlásících se $\mathrm{v}$ České republice $\mathrm{k}$ trendu kontaktního rodičovství. Byly analyzovány rozhovory s celkem čtyřmi ženami, které kojí tandemově dvě děti, přičemž mladší dítě je v batolecím věku a starší ve věku předškolním. Analýza byla provedena metodou IPA a byla identifikována celkem čtyři hlavní témata. Prvním tématem byla snaha udržet kojení za každou cenu - od útlumu kojení v těhotenství, po prudký nárůst po porodu až k ideálu samoodstavu. Druhým tématem byla matka uprostř̌ed - „Připadám si, že jsem pořád ... pořád mezi dětma ... fyzicky a psychicky ...uprostřed“ obsahující podtémata averze vưči staršímu dítěti a následná bagatelizace negativnich pocitů, potřeba nastavit si hranice a vnímané nevýhody tandemového kojení, které se matky snaži ,,nevnímat“. Třetím tématem bylo tandemové kojení jako jistota pro starší dítě v novém uspořádání rodiny a snaha matky o podporu sourozeneckých vztahů, obsahující podtémata kojení jako jistota, nástroj k uspokojování potřeb a regulaci chováni ditěte po narozeni mladšího sourozence; sourozenecké vztahy jako motivace k tandemového kojeni a rozhodnutí na dětech. Posledním, čtvrtým tématem, byla podpora i kritika tandemového kojení vedoucí k upevnění přesvědčení obsahující podtémata necítit se , divně“ diky podpoře a kritika tandemového kojení, která vede k upevnění postojů.

První téma je snaha udržet kojení za každou cenu - od útlumu kojení v těhotenství, po prudký nárůst po porodu až k ideálu samoodstavu a představuje průběh tandemového kojení u jednotlivých žen. Zdá se, že všechna čtyři tandemová kojení postupovala ve stejné trajektorii. U všech žen došlo k útlumu kojení během těhotenství, což je běžný stav, protože se mění chut', konzistence a množství mateřského mléka (Wambach \& Riordan, 2016) a u většiny dětí vede k přirozenému odstavení (Marquis et al., 2012). Ženy v tomto souboru ale projevily velké odhodlání kojení staršího dítěte během těhotenství udržet, jako důvody uváděly zejména zdravotní benefity, což se shoduje se zjištěním Fairclothové (2010a, b), která poukazuje na to, že motivací $\mathrm{k}$ dlouhodobému kojení u žen následujících trend kontaktního rodičovství jsou „vědecky podložené důkazy“ vypovídající o dlouhodobých zdravotních benefitech kojení. Nicméně, Fairclothová (2013) upozorňuje na to, že benefity kojení trvajícího přes rok života dítěte nebyly v žádném z výzkumů průkazně potvrzeny. Výzkumy zaměřující se na dlouhodobé kojení jsou svými výsledky poměrně nejasné a mají často problematickou metodologii (Wolf, 2013).

Druhým tématem bylo téma matka uprostřed - „Připadám si, že jsem pořád...pořád mezi dětma...fyzicky a psychicky...uprostřed“. Téma vypovídá o matce a jejím prožívání tandemového kojení. Třri ze čtyř žen popisovaly pocity averze a naštvání na starší dítě, a to jak během kojení v těhotenství, tak po narození mladšího dítěte. Negativní emoce u kojení jsou poměrně častým jevem, přestože se o tomto tématu moc nemluví (Heise \& Wiessinger, 2011). Vyskytují se zejména u žen kojících právě během těhotenství a kojících tandemově (Yate, 2017). Na základě několika výzkumů na toto téma z nedávné doby (např. Watkinson, Murray, \& Simpson, 2016) bylo zjištěno podobné prožívání averze u matek, které kojí dlouhodobě, tedy zpravidla dítě starší než jeden rok, nicméně přechozí výzkumy na toto téma byly provedeny často v zemích (např. ve Velké Británii), kde je kojení spíše okrajovou záležitostí a kojení nad šest měsíců věku dítěte je považováno spíše za výjimku (Dowling a kol., 2016). V České republice je kojení běžnější a podle dostupného výzkumu mateřství v České republice kojí většina žen alespoň do jednoho roku života dítěte (Masopustová a kol., 2016). I tak se podobné 
pocity objevují i u matek v prezentovaném výzkumu, zejména toto téma zmiňují Libuše a Leona, které $\mathrm{v}$ rámci tématu vlastního prožívání tandemového kojení mluví o tom, že je kojení staršího dítěte vyčerpává a mají na něj vztek, chtějí ale kojení udržet až do „samoodstavu“, protože „dělají to nejlepší pro své dítě“. K podobným zjištěním dochází i Fairclothová (2013), která si všímá, že součástí kontaktního rodičovství a dlouhodobého kojení u žen v La Leche League, které zkoumala, je právě aspekt jakéhosi „sebeobětování“. Sebeobětování a stavění vlastních potřeb na nižší úroveň jsou patrné i u žen v našem výzkumu, které mluví o prožívání negativních pocitů vůči staršímu dítěti a touhu starší dítě odstavit, ale zároveň své pocity bagatelizují a samy sebe přesvědčují, že je potřeba „to vydržet“. Například Yates (2017) se zamýšlí, zda je dlouhodobé kojení skutečně takovým benefitem, když matka sice dítě kojí, ale zároveň vůči němu zažívá silné negativní pocity. Je potřeba zdůraznit, že téma nevyhovujícího nastavení se objevovalo jen u poloviny žen v prezentovaném výzkumu.

V rámci tématu Matka uprostřed se objevovalo i podtéma potřeby nastavit si hranice. O potřebě nastavovat hranice $\mathrm{v}$ kojení zejména staršího dítěte mluvily všechny respondentky, přičemž se toto téma objevuje zejména u Libuše a Leony, které na jednu stranu popisují, že vidí obrovskou potřebu staršího dítěte se kojit, na druhou stranu popisují vlastní vyčerpání a nechut' ke kojení tak starého dítěte. V souladu s principy kontaktního rodičovství se tyto ženy pokoušejí naplňovat potřeby dítěte, jejich ideálem je „samoodstav“ a kojení na přání dítěte bez ohledu na věk dítěte, nicméně se u nich dostavují pocity napětí, frustrace a selhání, protože nejsou schopny tyto ideály naplňovat. Výsledkem je snaha o regulaci kojení staršího dítěte, která se ovšem Libuši ani Leoně př́liš nedaří, což může vést k prohloubení frustrace a vyčerpání. Téma nastavování hranic (nejen) v tandemovém kojení, ale celkově v kojení dlouhodobém, by mohlo být zajímavým námětem dalšího výzkumu. Vzhledem k tomu, že se dlouhodobé kojení týká starších dětí, a to v batolecím a předškolním věku, kdy se u většiny dětí rozvíjí schopnost reagovat také na potřeby jiných lidí a je na místě, aby byly děti v tomto věku konfrontovány s tím, že ne všechny jejich požadavky jsou okamžitě splněny (Dix, Stewart, Gershoff, \& Day, 2007), může být otázkou, nakolik se u nich vyvine schopnost odložit bezprostřední plnění svých prrání, pokud jsou jejich požadavky na kojení plněny okamžitě a kdekoliv.

Třetím tématem je téma tandemové kojení jako jistota pro starší dítě v novém uspořádání rodiny a snaha matky o podporu sourozeneckých vztahů. Všechny děti v prezentovaném výzkumu byly v c době, kdy jejich matka čekala další dítě, v batolecím věku. Přirozeně tedy docházelo k útlumu kojení, všechny ženy uvádějí, že se jejich starší dítě již téměř nekojilo nebo kojilo velmi omezeně. Prudká změna ale nastala po narození mladšího dítě, kdy u všech dětí došlo k nárůstu frekvence kojení, která trvala dlouhou dobu, což si respondentky vysvětlují jako snahu dítěte posílit jistotu, která mu byla příchodem mladšího dítěte narušena. Takové chování dítěte je přirozené, protože se po narození mladšího sourozence často setkáváme s regresí, kdy se dítě v reakci na stres po narození mladšího sourozence svým chováním vrací na nižší vývojovou úroveň (Volling, 2017), tedy v př́ípadě tandemového kojení k frekvenci kojení odpovídající spíše začátku kojeneckého věku a u dvou respondentek bylo spojeno také s odmítáním běžného jídla u staršího dítěte (u Mariky konkrétně starší syn ve věku dvou let přestal na několik měsíců jíst tuhou stravu a vrátil se k plnému kojení). Přechod $\mathrm{k}$ sourozenectví je pro dítě jedním z důležitých vývojových milníků, který s sebou může nést problémy v chování staršího dítěte, protože dochází k novému rodinnému uspořádání, kdy se z jedináčka stává starší sourozenec a je na své pozici (nejmladšího) dítěte nahrazeno novým dítětem (Campbell, 2002). Úkolem rodičů je dítěti v tomto období poskytnout dostatečnou 
emocionální podporu, pomoci mu náročné období překovat a ukotvit ho v novém uspořádání rodiny (Teti et al., 1996). Přetrvávající kojení staršího dítěte se v tomto smyslu může jevit rozporuplně. Na jednu stranu je kojením dítěti poskytována jistota, na kterou bylo zvyklé před narozením mladšího sourozence. Na druhou stranu může být ale dítě podporováno a ukotvováno v regresi chování a je mu poskytováno ujištění, že je stále v pozici „miminka“, což může být problematické pro nastavení nového uspořádání rodiny, které logicky po narození mladšího sourozence přichází (Teti el al., 1996).

V rámci třetího tématu analýzy popisují ženy v prezentovaném výzkumu jako motivaci $\mathrm{k}$ tandemovému kojení to, aby byl mezi sourozenci dobrý vztah, což se objevuje jako jedna z nejvýraznějších motivací k tandemovému kojení také ve výzkumu O’Rourkové (2019). Zároveň se ale u některých matek v našem výzkumu objevuje prožívání negativních pocitů a pocitů averze vůči staršímu dítěti (viz druhé téma analýzy). Teti a kol. (1996) zjišt'ují, že i přechod dítěte k sourozenectví je pozitivně podpořen, když je matka po narození mladšího sourozence $\mathrm{v}$ psychické pohodě. Zůstává tedy otázkou, do jaké míry může být schopnost staršího dítěte přijmout do rodiny mladšího sourozence ovlivněna vyčerpáním a dlouhodobým nevyhovujícím nastavením, které může matka v rámci tandemového kojení prožívat. Možné další výzkumné směřování by se mohlo soustředit na sourozenecké vztahy a schopnost přijmout mladšího sourozence u dětí kojených tandemově.

S vysokou frekvencí kojení staršího dítěte, která odpovídá spíše nižšímu vývojovému období, souvisí paradox, který byl u účastnic výzkumu patrný. Na jednu stranu potvrzovaly staršímu dítěti pozici „miminka“ v rodině tím, že jej kojily často (mnohdy častěji než mladší dítě), na druhou stranu na něj ale přesměrovávaly odpovědnost za důležitá rozhodnutí, jako je naprríklad to, kdy se kojit přestane. Podtéma odpovědnosti na dětech bylo dalším, které $\mathrm{z}$ analýzy tohoto tématu vzešlo a objevovalo se u všech respondentek. Jednak mluvily o samoodstavu, tedy ukončení kojení dítětem, jednak zmiňovaly ponechání odpovědnosti na dětech při rozhodování například v jídle (zda se chtějí kojit nebo jíst běžné jídlo) nebo hlídání. Tzv. „přistup řízený dítětem“ vzešel také z tematické analýzy dlouhodobě kojících žen $\mathrm{v}$ jednom z nejaktuálnějších výzkumů na toto téma Thompsona, Toppinga a Jonese (2020), kdy většina žen z jejich souboru uváděla, že hodně věcí nechávají na samotném dítěti. Vysoké nároky na schopnost dítěte se rozhodnout a přijmout odpovědnost nemusí v batolecím a předškolním věku odpovídat kognitivním schopnostem dítěte (Morasch \& Bell, 2010) a mohou se tedy jevit jako vývojově neadekvátní (Carlson, Moses, \& Breton, 2002). Př́stup k dítěti se tady tedy dostává do rozporu, kdy na jedné straně je k dítěti přistupováno, jako kdyby se nacházelo na vývojově nižší úrovni (co se týče frekvence kojení a bezprostředního plnění jeho potřeb, minimálně v kojení), a zároveň na druhé straně jsou na něj v oblasti rozhodování kladeny požadavky, které jeho aktuální vývojovou úroveň překračují.

Kojení staršího dítěte je všemi matkami v prezentovaném výzkumu označováno také jako „emočni'“, tedy plnící i jinou než výživovou funkci, zejména funkci uklidnění dítěte. Kojení jako způsob uklidnění dítěte v takových situacích je typický pro dlouhodobé kojení (Thompson, Topping, \& Jones, 2020) a kontaktní rodičovství (Faircloth, 2010a). Ženy v prezentovaném výzkumu uvádějí, že i starší dítě vyhledává kojení v situacích stresu, napětí, bolesti atd., což je typické spíše pro děti mladšího věku, kdy se jedná zejména v prvních měsících života o plně funkční a doporučovanou strategii (Carbajal et al., 2003). Nicméně s rozvíjející se vývojovou úrovní by mělo být dítě podněcováno k osvojování různorodějších a vyspělejších způsobů 
regulace emocí, přičemž může být $\mathrm{z}$ hlediska rozvoje regulačních mechanismů problematické, že je na frustraci a různou škálu emocí dítěte reagováno dlouhodobě pouze jedním způsobem, a to kojením (Masopustová \& Hanáčková, 2018). Právě absence vývojového úhlu pohledu bývá zmiňována jako jedno z nejčastějších rizik bezhlavého následování kontaktního rodičovství bez ohledu na věk dítěte (Connell-Carrick, 2006; Masopustová \& Hanáčková, 2018). Mohlo by být zajímavé další výzkumy na toto téma směřovat právě ke schopnosti žen následujících kontaktní rodičovství reflektovat ve svém prrístupu vývojové stadium dítěte, případně se zaměřit na schopnost emoční regulace u dětí, které jsou kojeny dlouhodobě, např́íklad až do předškolního věku, a u kterých je dlouhodobě používáno kojení ke zklidnění.

Posledním tématem je téma podpora i kritika tandemového kojení vedoucí $\mathbf{k}$ upevnění přesvědčení. Téma obsahuje podporu, která se matkám dostává, at’ už ze strany odborníkủ nebo ze strany sociální skupiny, ve které se matka nachází a kritika, která přichází ze strany okolí. Téma podpory i kritiky se objevovalo v nějaké formě u všech respondentek. Výrazným tématem byla podpora sociální skupiny žen, které praktikují stejný rodičovský prŕístup, kojí dlouhodobě a schvalují tandemové kojení. Libuše mluví o tom, že právě tato skupina ji pomohla v ukotvení jejích názorů a že jí dala pocit, že někam ,zapadá“. Leona pak vyloženě vyměnila skupinu matek, které její dlouhodobé a tandemové kojení neschvalovaly, za novou skupinu žen používající stejné rodičovské praktiky jako Leona. Právě podporu jiných žen jako klíčovou zmiňovaly matky i v jiných výzkumech zaměřených na prožíání dlouhodobé kojení (Tomori, Palmquist, \& Dowling, 2016; Faircloth, 2013; Thompson, Topping, \& Jones, 2020). Jedna z účastnic našeho výzkumu dokonce uvádí podporu laktační poradkyně v tandemovém kojení jako tak důležitou, že ji označuje za důvod svého tandemového kojení, protože jí pomohla si tandemové kojení „dovolit“. V jiných výzkumech na toto téma (např. Tomori, Palmquist, \& Dowling, 2016) bývají odborníci zmiňovaní spíše v souvislosti s kritikou tandemového kojení a s odrazováním žen od takovýchto praktik. Nicméně v našem výzkumu se respondentky setkaly i s podporou ze strany odborníků. Jedna z respondentek uvádí svou gynekoložku, která jí tandemové kojení schválila a podporovala ji v něm. Kritika ze strany odborníků se, podobně jako v jiných výzkumech (např. Thompson, Topping, \& Jones, 2020), objevuje zejména od odborníků v porodnici po narození mladšího dítěte. Marika sděluje, že ji lékaři odrazovali od kojení staršího dítěte po porodu, aby bylo dost „dobrého“ mléka (nejspíš myšleno kolostra) pro mladší, $v$ té době novorozené, dítě. Nicméně, podobně jako se nepodařilo dohledat výzkumnou podporu pro výrazné benefity dlouhodobého kojení, nepodařilo se dohledat ani rizika pro kojení dvou dětí zároveň. Jediný výzkum na toto téma (Marquis et al., 2012) dochází k závěru, že u žen kojících během posledního trimestru těhotenství mělo mladší dítě ve třech měsících věku nižší váhu než u žen nekojících během posledního trimestru těhotenství. Závěry ovšem nebyly potvrzeny v žádném jiném dohledaném výzkumu a nebylo zjištěno, zda nižší váha dětí přetrvává delší dobu, proto je problematické činit závěry.

Další kritika dlouhodobého kojení u žen v prezentovaném výzkumu pocházela od širších rodinných př́śslušníků, což se shoduje i s jinými výzkumy (Faircloth, 2010a), přičemž kritika cílila zejména na kojení staršího dítěte. Je zajímavé, že kojení mladšího dítěte, tedy dítěte ve věku kolem dvou let, se s kritikou nesetkávalo, což se neshoduje se závěry výzkumů ze zahraničí, kdy ženy kojící dlouhodobě narážely na odpor ke svému kojení už od cca šesti měsíců věku dítěte (Tomori, Palmquist, \& Dowling, 2016) nebo př́padně od roku věku dítěte (Thompson, Topping, \& Jones, 2020). Vnímané akceptování kojení dítěte batolecího věku u respondentek v našem souboru podporují předpoklad, že přistup ke kojení je i v rámci 
evropských zemí rozdílný a že se vnímání dlouhodobého kojení v České republice spíše podobá např́íklad situaci na Islandu, kde je běžné kojit i starší děti (Símonardóttir \& Gíslason, 2018). Závěrem stojí za zmínku reakce na kritiku u žen v prezentovaném výzkumu, která u nich vedla spíše než ke zpochybňování svého přístupu k jeho upevňování. S podobným jevem se ve svých výzkumech setkává Fairclothová (2010a, b; 2013), podle níž dochází u žen vzájemně se podporujících a vymezujících se proti kritice okolí, ale i proti jiným rodičovským př́stupům, k silnějšímu upevňování mateřské identity, která je onou kritikou ohrožena.

Limitem prezentovaného výzkumu je relativně nízký počet respondentek. Vzhledem $\mathrm{k}$ tomu, že cílem bylo vytvořit homogenní skupinu respondentek, které měly podobně silný vztah ke kontaktnímu rodičovství, zároveň kojily tandemově, a to děti v podobném věku (batole a předškoláka), nepodařilo se do výzkumu zahrnout více žen, které by tato kritéria splňovaly.

Studie vznikla v rámci projektu specifického výzkumu MUNI/A/1491/2020.

\section{Literatura}

Bryant T. (2012). Tandem nursing: a review and guidelines. International Journal Childbirth Education, 27, 84-88.

Carbajal, R. et al. (2003). Analgesic effect of breast feeding in term neonates: Randomised controlled trial. BMJ, 326(7379), 13-13. https://doi.org/10.1136/bmj.326.7379.13

Carlson, S. M., Claxton, L. J., \& Moses, L. J. (2015). The relation between executive function and theory of mind is more than skin deep. Journal of Cognition and Development, 16(1), 186-197. https://doi.org/10.1080/15248372.2013.824883

Crossley, M. L. (2009). Breastfeeding as a moral imperative: An Autoethnographic study. Feminism \& Psychology, 19(1), 71-87. https://doi.org/10.1177/0959353508098620

Dix, T., Stewart, A. D., Gershoff, E. T., \& Day, W. H. (2007). Autonomy and children's reactions to being controlled: Evidence that both compliance and defiance may be positive markers in early development. Child Development, 78, $1204-1221$. http://dx.doi.org/10.1111/j.1467-8624.2007.01061.x

Dowling, S., \& Brown, A. (2013). An exploration of the experiences of mothers who breastfeed long-term: What are the issues and why does it matter? Breastfeeding Medicine, 8(1), 45-52. https://doi.org/10.1089/bfm.2012.0057

Dowling, S., \& Pontin, D. (2016). Using liminality to understand mothers' experiences of long-term breastfeeding: 'Betwixt and between', and 'matter out of place'. Health: An Interdisciplinary Journal for the Social Study of Health, Illness and Medicine, 21(1), 5775. https://doi.org/10.1177/1363459315595846

Duncan, B. (1993). Exclusive breast-feeding for at least 4 months protects against otitis media. The Nurse Practitioner, 18(7), 7-8. https://doi.org/10.1097/00006205-19930700000002

Dykes F. \& Flacking R. (2010). Encouraging breastfeeding: a relational perspective. Early Human Development 86, 733-736. https://doi.org/10.1016/j.earlhumdev.2010.08.004

Faircloth, C. R. (2010). 'If they want to risk the health and well-being of their child, that's up to them': Longterm breastfeeding, risk and maternal identity. Health, Risk \& Society, 12(4), 357-367. https://doi.org/10.1080/13698571003789674 
Faircloth, C. (2013). Militant Lactivism? Attachment Parenting and Intensive Motherhood in the UK and France. Berghahn.

Hauck, Y., \& Irurita, V. (2003). Incompatible expectations: The dilemma of breastfeeding mothers. Health Care for Women International, 24(1), 62-78. https://doi.org/10.1080/07399330390170024

Heise, A. M., \& Wiessinger, D. (2011). Dysphoric milk ejection reflex: A case report. International Breastfeeding Journal, 6(1). https://doi.org/10.1186/1746-4358-6-6

Kochanska, G., \& Aksan, N. (1995). Mother-child mutually positive affect, the quality of child compliance to requests and prohibitions, and maternal control as correlates of early internalization. Child Development, 66(1), 236. https://doi.org/10.2307/1131203

Kull, I. (2002). Breast feeding and allergic diseases in infants--a prospective birth cohort study. Archives of Disease in Childhood, 87(6), 478-481. https://doi.org/10.1136/adc.87.6.478

Larsen, J. S., \& Kronborg, H. (2012). When breastfeeding is unsuccessful - mothers' experiences after giving up breastfeeding. Scandinavian Journal of Caring Sciences, 27(4), 848-856. https://doi.org/10.1111/j.1471-6712.2012.01091.x

Lee, E.; Bristow, J., (2009). Rules for feeding babies. In S.D. Sclater et al.(eds.), Regulating autonomy: Sex, reproduction and family. 73-91. Hart.

Maher, J., \& Saugeres, L. (2007). To be or not to be a mother? Journal of Sociology, 43(1), 521. https://doi.org/10.1177/1440783307073931

Mangrio, E., Persson, K., \& Bramhagen, A. (2017). Sociodemographic, physical, mental and social factors in the cessation of breastfeeding before 6 months: A systematic review. Scandinavian Journal of Caring Sciences, 32(2), 451-465. https://doi.org/10.1111/scs.12489

Marquis, G. S., Penny, M. E., Diaz, J. M., \& Marin, R. M. (2002). Postpartum consequences of an overlap of breastfeeding and pregnancy: Reduced breast milk intake and growth during early infancy. Pediatrics, 109(4), e56-e56. https://doi.org/10.1542/peds.109.4.e56

Marshall, J.L. (2011). Motherhood, breastfeeding and identity. Practising Midwife 14, 16-18.

Masopustová, Z., \& Hanáčková, V. (2018). Trendy v rodičovství. In Z. Masopustová, P. Daňsová, L. Lacinová a kol. (Eds.), Jak to mají mámy. Psychologický výzkum mateřství (pp. 36-43). Muni Press.

McInnes, R. J., \& Chambers, J. A. (2008). Supporting breastfeeding mothers: Qualitative synthesis. Journal of Advanced Nursing, 62(4), 407-427. https://doi.org/10.1111/j.13652648.2008.04618.x

Morasch, K. C., \& Bell, M. A. (2012). Self-regulation of negative affect at 5 and 10 months. Developmental Psychobiology, 54, 215-21. https://doi.org/10.1002/dev.20584

Morns, M. A., Steel, A. E., Burns, E., \& McIntyre, E. (2021). Women who experience feelings of aversion while breastfeeding: A meta-ethnographic review. Women and Birth, 34(2), 128-135. https://doi.org/10.1016/j.wombi.2020.02.013

Murphy, E. (1999). 'Breast is best': Infant feeding decisions and maternal deviance. Sociology of Health and Illness, 21(2), 187-208. https://doi.org/10.1111/1467-9566.00149

Newman, K. L., \& Williamson, I. R. (2018). Why aren't you stopping now?!' exploring accounts of white women breastfeeding beyond six months in the east of England. Appetite, 129, 228-235. https://doi.org/10.1016/j.appet.2018.06.018

Oddy, W. (2007). 5E-2 the impact of breastfeeding on long-term child health and development. Early Human Development, 83, S43. https://doi.org/10.1016/s03783782(07)70044-0 
O'Rourke, M. P. (2018). Women's experiences with tandem breastfeeding. MCN: The American Journal of Maternal/Child Nursing, 44(4), 220-227. https://doi.org/10.1097/nmc.0000000000000534

Rollins, N. C., Bhandari, N., Hajeebhoy, N., Horton, S., Lutter, C. K., Martines, J. C., Piwoz, E. G., Richter, L. M., \& Victora, C. G. (2016). Why invest, and what it will take to improve breastfeeding practices? The Lancet, 387(10017), 491-504. https://doi.org/10.1016/s0140-6736(15)01044-2.

Säilävaara, J. (2019). Long-term breastfeeding: The embodied experiences of Finnish mothers. NORA - Nordic Journal of Feminist and Gender Research, 28(1), 43-55. https://doi.org/10.1080/08038740.2019.1694581

Sears, W., \& Sears, M. (2003). Kontaktní rodičovství: rozumná cesta k pochopení a výchově dětí. Argo.

Símonardóttir, S. (2016). Constructing the attached mother in the "world's most feminist country”. Women's Studies International Forum, 56, 103-112. https://doi.org/10.1016/j.wsif.2016.02.015

Símonardóttir, S., \& Gíslason, I. V. (2018). When breast is not best: Opposing dominant discourses on breastfeeding. The Sociological Review, 66(3), 665-681. https://doi.org/10.1177/0038026117751342

Slusser, W. (2007). Breastfeeding and maternal and infant health outcomes in developed countries. AAP Grand Rounds, 18(2), 15-16. https://doi.org/10.1542/gr.18-2-15

Stearns, C. A. (2011). Cautionary tales about extended breastfeeding and weaning. Health Care for Women International, 32(6), 538-554. https://doi.org/10.1080/07399332.2010.540051

Teti, D. M., Sakin, J. W., Kucera, E., Corns, K. M., \& Eiden, R. D. (1996). And baby makes four: Predictors of attachment security among preschool-age Firstborns during the transition to Siblinghood. Child Development, 67(2), 579. https://doi.org/10.2307/1131833

Theurich, M. A., Davanzo, R., Busck-Rasmussen, M., Díaz-Gómez, N. M., Brennan, C., Kylberg, E., Bærug, A., McHugh, L., Weikert, C., Abraham, K., \& Koletzko, B. (2019). Breastfeeding rates and programs in Europe: A survey of 11 national breastfeeding committees and representatives. Journal of Pediatric Gastroenterology \& Nutrition, 68(3), 400-407. https://doi.org/10.1097/mpg.0000000000002234

Thomson, G., Ebisch-Burton, K., \& Flacking, R. (2014). Shame if you do - shame if you don't: Women's experiences of infant feeding. Maternal \& Child Nutrition, 11(1), 33-46. https://doi.org/10.1111/mcn.12148

Van den Berg, M., \& Ball, H. L. (2008). Practices, advice and support regarding prolonged breastfeeding: A descriptive study from Sri Lanka. Journal of Reproductive and Infant Psychology, 26(3), 229-243. https://doi.org/10.1080/02646830701691376

Volling, B. L. (2017). Xi. General discussion: Children's adjustment and adaptation following the birth of a sibling. Monographs of the Society for Research in Child Development, 82(3), 142-158. https://doi.org/10.1111/mono.12317

Wambach, K., \& Riordan, J. (Eds.). (2016). Breastfeeding and human lactation (5th ed.). Jones \& Bartlett Learning.

Watkinson, M., Murray, C., \& Simpson, J. (2016). Maternal experiences of embodied emotional sensations during breast feeding: An interpretative phenomenological analysis. Midwifery, 36, 53-60. https://doi.org/10.1016/j.midw.2016.02.019 
Yate, Z. (2017). A qualitative study on negative emotions triggered by breastfeeding; Describing the phenomenon of breastfeeding/nursing aversion and agitation in breastfeeding mothers. Iranian Journal of Nursing and Midwifery Research, 22(6), 449. https://doi.org/10.4103/ijnmr.ijnmr_235_16

\section{O autorkách}

Mgr. Veronika Hanáčková, Ph.D. působila na Katedře psychologie Fakulty sociálních studií Masarykovy univerzity v Brně, kde v červnu 2021 dokončila doktorské studium oboru Vývojová psychologie.

\section{Kontaktní údaje:}

Adresa: Katedra psychologie, Fakulta sociálních studií, Masarykova univerzita, Joštova 10, Brno

E-mail: v.hanackova12@gmail.com

Mgr. Zuzana Masopustová, Ph.D. působí na Katedře psychologie Fakulty sociálních studií Masarykovy univerzity v Brně. Dlouhodobě se věnuje problematice rodičovství a raného vývoje.

\section{Kontaktní údaje:}

Adresa: Katedra psychologie, Fakulta sociálních studií, Masarykova univerzita, Joštova 10, Brno

E-mail: zuzana.masopustova@fss.muni.cz

Hanáčková, V., \& Masopustová, Z. (2021). Tandemové kojení jako specifický prostředek kontaktního rodičovství - zkušenosti matek. E-psychologie, 15(4), 14-39.

https://doi.org/10.29364/epsy.419 